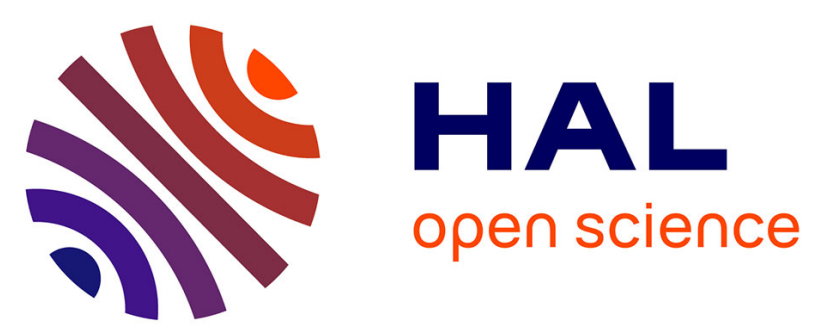

\title{
Activation of ceramide synthase 6 by celecoxib leads to a selective induction of C-ceramide
}

\author{
Susanne Schiffmann, Simone Ziebell, Jessica Sandner, Kerstin Birod, Klaus \\ Deckmann, Daniela Hartmann, Sina Rode, Helmut Schmidt, Carlo Angioni, \\ Gerd Geisslinger, et al.
}

\section{To cite this version:}

Susanne Schiffmann, Simone Ziebell, Jessica Sandner, Kerstin Birod, Klaus Deckmann, et al.. Activation of ceramide synthase 6 by celecoxib leads to a selective induction of C-ceramide. Biochemical Pharmacology, 2010, 80 (11), pp.1632. 10.1016/j.bcp.2010.08.012 . hal-00632284

\section{HAL Id: hal-00632284 \\ https://hal.science/hal-00632284}

Submitted on 14 Oct 2011

HAL is a multi-disciplinary open access archive for the deposit and dissemination of scientific research documents, whether they are published or not. The documents may come from teaching and research institutions in France or abroad, or from public or private research centers.
L'archive ouverte pluridisciplinaire $\mathbf{H A L}$, est destinée au dépôt et à la diffusion de documents scientifiques de niveau recherche, publiés ou non, émanant des établissements d'enseignement et de recherche français ou étrangers, des laboratoires publics ou privés. 


\section{Accepted Manuscript}

Title: Activation of ceramide synthase 6 by celecoxib leads to a selective induction of $\mathrm{C}_{16: 0}$-ceramide

Authors: Susanne Schiffmann, Simone Ziebell, Jessica Sandner, Kerstin Birod, Klaus Deckmann, Daniela Hartmann, Sina Rode, Helmut Schmidt, Carlo Angioni, Gerd Geisslinger,

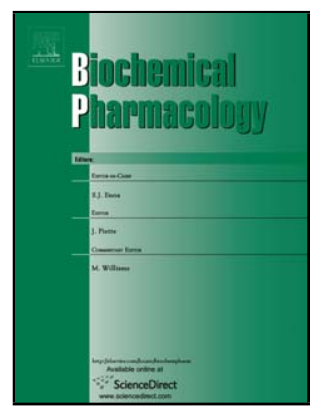
Sabine Grösch

PII:

S0006-2952(10)00621-0

DOI: doi:10.1016/j.bcp.2010.08.012

Reference: BCP 10691

To appear in: $\quad B C P$

Received date: $\quad 28-6-2010$

Revised date: $\quad 12-8-2010$

Accepted date: $\quad$ 13-8-2010

Please cite this article as: Schiffmann S, Ziebell S, Sandner J, Birod K, Deckmann K, Hartmann D, Rode S, Schmidt H, Angioni C, Geisslinger G, Grösch S, Activation of ceramide synthase 6 by celecoxib leads to a selective induction of $\mathrm{C}_{16: 0}$-ceramide, Biochemical Pharmacology (2010), doi:10.1016/j.bcp.2010.08.012

This is a PDF file of an unedited manuscript that has been accepted for publication. As a service to our customers we are providing this early version of the manuscript. The manuscript will undergo copyediting, typesetting, and review of the resulting proof before it is published in its final form. Please note that during the production process errors may be discovered which could affect the content, and all legal disclaimers that apply to the journal pertain. 
Ceramide synthase 6 is activated by celecoxib

\title{
Activation of ceramide synthase 6 by celecoxib leads to a selective induction of $\mathrm{C}_{16: 0^{-}}$ ceramide
}

Running title: Ceramide synthase 6 is activated by celecoxib Classification: antibiotics and chemotherapeutics

\author{
Susanne Schiffmann, Simone Ziebell, Jessica Sandner, Kerstin Birod, Klaus Deckmann, \\ Daniela Hartmann, Sina Rode, Helmut Schmidt, Carlo Angioni, Gerd Geisslinger and \\ Sabine Grösch.
}

\section{pharmazentrum frankfurt/ZAFES, Institut für Klinische Pharmakologie, Klinikum der Goethe-} Universität Frankfurt, Theodor-Stern-Kai 7, 60590 Frankfurt/Main, Germany. Running head: Ceramide synthase 6 is activated by celecoxib

Corresponding author:

Susanne Schiffmann, PhD

Goethe-University/Institute of Clinical Pharmacology

Theodor-Stern-Kai 7 60590 Frankfurt/Main, Germany

Phone: $+49 / 69-63017820$

Fax: +49/69-6301 7636

E-mail: susanne.schiffmann@med.uni-frankfurt.de

key words: cancer, cyclooxygenase-2, (dihydro)ceramide synthase, $\mathrm{C}_{16: 0}$-ceramide, celecoxib, siRNA 


\section{ABSTRACT}

4 Ceramides serve as bioactive molecules with important roles in cell proliferation and apoptosis.

5 Ceramides (Cer) with different $\mathrm{N}$-acyl side chains $\left(\mathrm{C}_{14: 0} \mathrm{-} \mathrm{Cer}-\mathrm{C}_{26: 0}\right.$-Cer) possess distinctive roles

6 in cell signaling and are differentially expressed in HCT-116 colon cancer cells. Celecoxib, a

7 selective cyclooxygenase-2 (COX-2) inhibitor, exhibiting antiproliferative effects, activates the

8 sphingolipid pathway. To elucidate the mechanism, HCT-116 cells were treated with $50 \mu \mathrm{M}$

9 celecoxib leading to a significant increase of $\mathrm{C}_{16: 0}$-Cer. Interestingly, $50 \mu \mathrm{M}$ celecoxib resulted in

10 a 2.8 fold increase of ceramide synthase (CerS) activity as measured by a cell-based activity 11 assay. siRNA against several CerSs revealed that CerS6 was predominantly responsible for the

12 increase of $\mathrm{C}_{16: 0}$-Cer in HCT-116 cells. Moreover, the silencing of CerS6 partially protected 13 HCT-116 cells from the toxic effects induced by celecoxib. Treatment of cells with celecoxib and 14 fumonisin B1 (inhibitor of CerSs) or myriocin (inhibitor of L-serine palmitoyl transferase) or 15 desipramine (inhibitor of acid sphingomyelinase and acid ceramidase) revealed that the increase 16 of $\mathrm{C}_{16: 0^{-}}$-Cer results predominantly from activation of the salvage pathway. Using the nude mouse 17 model we demonstrated that celecoxib induces also in vivo a significant increase of $\mathrm{C}_{16: 0}$-Cer in 18 stomach, small intestine and tumor tissue. In conclusion, celecoxib causes a specific increase of $19 \mathrm{C}_{16: 0^{-}}$-Cer by activating CerS6 and the salvage pathway, which contribute to the toxic effects of 20 celecoxib.

Abbreviations: Cer, ceramide; COX-2, cyclooxygenase-2; dhCer, dihydroceramide; CerS, (dihydro)ceramide synthase; DES, dihydroceramide desaturase; FB1, fumonisin B1, GCS, glucosylceramide synthase; KSR, 3-ketosphinganine reductase; Myr, myriocin, SMS, sphingomyelin synthase; SMase, sphingomyelinase; Sph1P, sphingosine-1-phosphate; Sph1PP, sphingosine-1-phosphate phosphatase; dhSph, sphinganine; dhSph1P, sphinganine-1-phosphate; SPT, L-serine palmitoyl transferase. 


\section{$1 \quad$ 1. Introduction}

4 As the backbone of several complex sphingolipids (sphingomyelins, glycosylceramides),

5 ceramides are members of the rapidly expanding field of bioactive lipids, which play important

6 roles in the regulation of cell growth, cell differentiation, apoptosis and cell senescence [1].

7 Briefly, ceramides are synthesized de novo from L-serine and palmitoyl-CoA, which are

8 converted subsequently by L-serine palmitoyl transferase (SPT) and 3-ketosphinganine reductase

9 to sphinganine. Acyl-CoAs with chain lengths between $\mathrm{C}_{14}-\mathrm{C}_{26}$ are attached to sphinganine by 10 chain length specific (dihydro)ceramide synthases (CerS1-6) [2] to form $\mathrm{C}_{14^{-}} \mathrm{C}_{26^{-}}$ 11 dihydroceramides. Dihydroceramide desaturase converts these intermediates to $\mathrm{C}_{14^{-}} \mathrm{C}_{26^{-}}$ 12 ceramides. Sphingosine, produced by the salvage pathway, is also accepted by these CerSs as a 13 substrate, leading to the synthesis of $\mathrm{C}_{14}-\mathrm{C}_{26}$-ceramides without the intermediate 14 dihydroceramide (figure 1A). In some tissues such as the testes, ceramides of lengths up to $\mathrm{C}_{32}$ 15 have been detected [3]. As an alternative to de novo synthesis, complex sphingolipids may be 16 degraded to ceramides and subsequently to sphingosine in the lysosome as part of the salvage 17 pathway (figure 1A).

18 The CerS isoforms differ in their substrate specificities and their tissue distribution. Recent 19 publications [4-7] on substrate specificity using cell culture experiments assigned the CerS 20 isoforms to various $\mathrm{N}$-acyl side chains starting with the short chain ceramides as follows: CerS5 21 ( $\mathrm{C}_{16: 0^{-}}$Cer, $\mathrm{C}_{18: 0^{-}}$Cer, $\mathrm{C}_{18: 1^{-}}$Cer $)$; CerS6 (C $\mathrm{C}_{16: 0^{-}}$Cer, $\left.\mathrm{C}_{18: 0^{-}} \mathrm{Cer}\right)$; CerS1 ( $\left.\mathrm{C}_{18: 0^{-}} \mathrm{Cer}\right)$; CerS3 $\left(\mathrm{C}_{18: 0^{-}}\right.$ 22 Cer, $\left.\mathrm{C}_{20: 0}-\mathrm{Cer}\right)$; CerS4 $\left(\mathrm{C}_{18: 0}-\mathrm{Cer}, \mathrm{C}_{20: 0}\right.$-Cer, $\left.\mathrm{C}_{22: 0}-\mathrm{Cer}, \mathrm{C}_{24: 0}-\mathrm{Cer}\right)$; CerS2 $\left(\mathrm{C}_{20: 0}-\mathrm{Cer}, \mathrm{C}_{22: 0}-\mathrm{Cer}_{\text {, }}\right.$ $23 \mathrm{C}_{24: 0}$-Cer). These data indicate a substantial degree of overlap in substrate specificity among the 24 isoforms, obscuring assignment of a specific ceramide to a specific CerS isoform. 
1 Ceramides exhibit antiproliferative and proapoptotic effects [8]. Several chemotherapeutics are

2 known to induce apoptosis and/or inhibit cell growth via generation and accumulation of 3 ceramides, either via activation of de novo synthesis or through the salvage pathway by the 4 hydrolysis of sphingomyelin by sphingomyelinases (SMase) [9-10]. Which of these pathways are 5 activated depends on the cell type and stimulus (for review see [11]). Interestingly, there are 6 early data suggesting that cancer cells, but not normal cells, are hyper-sensitive to ceramides, 7 thereby raising the sphingolipid pathway as a possible target for cancer therapy [12-13].

8 Celecoxib, a selective COX-2 inhibitor, exhibits pro-apoptotic and growth inhibiting effects in

9 various cancer cells and animal tumor models [14]. It is approved for the adjuvant treatment of 10 familial adenomatous polyposis, an inherited syndrome that predisposes individuals to colon 11 cancer [15]. The antiproliferative activity of celecoxib correlates with inhibition of COX-2 as 12 well as with its ability to inhibit non-COX-2 targets such as 3-phosphoinositide-dependent 13 protein kinase-1 (PDK1), sarcoplasmic/endoplasmic reticulum calcium ATPase (SERCA) [16] 14 and 5-lipoxygenase [17].

15 A previous study from our group demonstrated that celecoxib influences the sphingolipid 16 pathway by inhibiting dihydroceramide desaturase with an $\mathrm{IC}_{50}$ of $79 \mu \mathrm{M}$ [18]. In addition to a 17 specific decrease of $\mathrm{C}_{24: 0}-\mathrm{Cer} / \mathrm{C}_{24: 1}$-Cer concentration and an increase of dihydroceramide 18 concentration, we also observed an elevation of total ceramide (ceramides and dihydroceramides) 19 levels, which were causatively linked to the apoptotic and growth inhibiting properties of 20 celecoxib. This increase in total ceramide levels after celecoxib treatment cannot exclusively be 21 explained by inhibition of the dihydroceramide desaturase. Therefore, we looked for further 22 targets in the sphingolipid pathway that also could be influenced by celecoxib and thereby 23 contribute to the observed changes in the sphingolipid levels in HCT-116 cells. 


\section{2. Experimental}

$4 \quad 2.1$ Cells and reagents

5 The human cancer cell line HCT-116 was ordered from Deutsche Sammlung für

6 Mikroorganismen und Zellkulturen (DSMZ, Braunschweig, Germany). HCT-116 cells were

7 incubated in McCoy's 5A supplemented with 100 units $/ \mathrm{ml}$ penicillin G, $100 \mu \mathrm{g} / \mathrm{ml}$ streptomycin,

$8 \quad 10 \%$ FCS (fetal calf serum) for culturing and 7.5 \% FCS in case of treatment. Cells were cultured

9 at $37{ }^{\circ} \mathrm{C}$ in an atmosphere containing $5 \% \mathrm{CO}_{2}$. Myriocin, fumonisin $\mathrm{B} 1$ and desipramine were

10 purchased from Sigma-Aldrich (Schnelldorf, Germany). siRNAs (CerS2 (s26788), CerS4

11 (s35896), CerS5 (s40552), CerS6 (s48449)) were purchased from Ambion (Darmstadt,

12 Germany). The sphingolipids and palmitoyl-CoA were purchased either from Avanti Polar

13 Lipids (Alabaster, USA) or Matreya LLC (Pleasant Gap, USA). Celecoxib was synthesized by

14 WITEGA Laboratorien Berlin-Adlershof GmbH. The identity and purity of celecoxib was

15 determined using ${ }^{1 \mathrm{H}} \mathrm{NMR}$ (nuclear magnetic resonance) spectroscopy and high performance

16 liquid chromatography (HPLC) as described previously [19] and was > $99 \%$.

192.2 Determination of sphingolipid concentrations in cells and in mouse tissue

20 For the quantification of sphingolipid amounts, cells were seeded at a density of $0.5 \times 10^{6} / 5 \mathrm{~cm}$

21 dish and incubated for $24 \mathrm{~h}$. Subsequently, cells were treated with celecoxib in the presence or

22 the absence of $150 \mathrm{nM}$ myriocin and/or $5 \mu \mathrm{M}$ sphingosine $\left(\mathrm{C}_{17}\right)$ over various periods of time. The

23 sphingolipids were extracted with methanol as previously described [18]. The mouse tissue was

24 homogenated in PBS and extracted with a mixture of chloroform/methanol (7:1). The extraction

25 and the determination of the sphingolipid concentrations $\left(\mathrm{C}_{16: 0^{-}} \mathrm{Cer}, \mathrm{C}_{18: 0^{-}}-\mathrm{Cer}, \mathrm{C}_{20: 0^{-}}-\mathrm{Cer}, \mathrm{C}_{24: 1^{-}}\right.$ 
1 Cer, $\mathrm{C}_{24: 0}$-Cer, $\mathrm{C}_{16: 0}$-dhCer, $\mathrm{C}_{24: 1}$-dhCer, $\mathrm{C}_{24: 0}$-dhCer, dhSph, Sph) by liquid chromatography

2 coupled to tandem mass spectrometry (LC-MS/MS) was achieved as published previously [18,

3 20]. Ceramides labeled by the introduction of $\mathrm{Sph}\left(\mathrm{C}_{17}\right)$ exhibit precursor-to-product ion

4 transitions of $\mathrm{m} / \mathrm{z} 496 \rightarrow 250$ for $\mathrm{C}_{14: 0}-\operatorname{Cer}\left(\mathrm{C}_{17}\right)$, of $\mathrm{m} / \mathrm{z} 524 \rightarrow 250$ for $\mathrm{C}_{16: 0^{-}}-\operatorname{Cer}\left(\mathrm{C}_{17}\right)$, of $\mathrm{m} / \mathrm{z}$ $5 \quad 552 \rightarrow 250$ for $\mathrm{C}_{18: 0^{-}} \operatorname{Cer}\left(\mathrm{C}_{17}\right)$, of $\mathrm{m} / \mathrm{z} 580 \rightarrow 250$ for $\mathrm{C}_{20: 0^{-}} \operatorname{Cer}\left(\mathrm{C}_{17}\right)$, of $\mathrm{m} / \mathrm{z} 608 \rightarrow 250$ for $\mathrm{C}_{22: 0^{-}}$

$6 \operatorname{Cer}\left(\mathrm{C}_{17}\right)$, of $\mathrm{m} / \mathrm{z} \quad 634 \rightarrow 250$ for $\mathrm{C}_{24: 1}-\operatorname{Cer}\left(\mathrm{C}_{17}\right)$, of $\mathrm{m} / \mathrm{z} 636 \rightarrow 250$ for $\mathrm{C}_{24: 0}-\operatorname{Cer}\left(\mathrm{C}_{17}\right)$, of $\mathrm{m} / \mathrm{z}$ $7 \quad 662 \rightarrow 250$ for $\mathrm{C}_{26: 0}-\operatorname{Cer}\left(\mathrm{C}_{17}\right)$, of $\mathrm{m} / \mathrm{z} 552 \rightarrow 534$ for $\mathrm{C}_{17: 0}$-Cer and of $\mathrm{m} / \mathrm{z} 286 \rightarrow 268$ for $\operatorname{Sph}\left(\mathrm{C}_{17}\right)$,

8 which were used for the Multiple Reaction Monitoring with a dwell time of 15 msec. For

9 analysis, the area under the peak of the analyte was related to the area under the peak of the 10 internal standard. The relative increase of the specific ceramides was calculated using the ratio of 11 analyte to internal standard of untreated cells as the value of $100 \%$. Data were normalized to the 12 number of treated cells.

$15 \quad 2.3$ Determination of palmitoyl-CoA concentrations in cells

16 For the quantification of palmitoyl-CoA $\left(\mathrm{C}_{16: 0^{-}} \mathrm{CoA}\right)$ amounts, cells were seeded at a density of $170.5 \times 10^{6}$, incubated for $24 \mathrm{~h}$ and incubated with $50 \mu \mathrm{M}$ celecoxib for various times. Lipids were 18 extracted with $125 \mu \mathrm{l}$ acetonitrile/water (50:50, v/v) after the addition of the internal standard $19\left(\mathrm{C}_{17: 0}-\mathrm{CoA}\right)$. The suspension was sonicated on ice, thoroughly mixed for $1 \mathrm{~min}$ and centrifuged 20 for $3 \mathrm{~min}$ at $25^{\circ} \mathrm{C}$ and $20,500 \mathrm{~g}$. The supernatants were collected and the extraction step (no 21 sonication) was repeated with $100 \mu \mathrm{l}$ acetonitrile/water (50:50, v/v). The amounts of $\mathrm{C}_{16: 0}-\mathrm{CoA}$ 22 and the internal standard were determined by LC-MS/MS. Chromatographic separation was 23 accomplished under gradient conditions using a Gemini C18 column (150 mm x $2 \mathrm{~mm}$ ID, $5 \mu \mathrm{m}$ 24 particle size; Phenomenex, Aschaffenburg, Germany). The HPLC mobile phases consisted of 
1 water/ammonium hydroxide (100:0.5, v/v) (A) and acetonitrile/ammonium hydroxide (100:0.5, $2 \mathrm{v} / \mathrm{v})(\mathrm{B}) . \mathrm{MS} / \mathrm{MS}$ analyses were performed on an API 5500 triple quadrupole mass spectrometer 3 with a Turbo V source (Applied Biosystems, Darmstadt, Germany) in the negative ion mode.

4 Precursor-to-product ion transitions of $\mathrm{m} / \mathrm{z} 501,7 \rightarrow 78,9$ for $\mathrm{C}_{16: 0}-\mathrm{CoA}$ and of $\mathrm{m} / \mathrm{z} 508,6 \rightarrow 78,9$

5 for $\mathrm{C}_{17: 0}-\mathrm{CoA}$ were used for the MRM with a dwell time of $200 \mathrm{msec}$. Concentrations of the 6 calibration standards, quality controls and unknowns were evaluated by Analyst software version 71.5 (Applied Biosystems). Linearity of the calibration curve was proven from $1 \mathrm{ng} / \mathrm{ml}(0.94$ $8 \mathrm{pmol} / \mathrm{ml})-100 \mathrm{ng} / \mathrm{ml}(94 \mathrm{pmol} / \mathrm{ml})$. The coefficient of correlation for all measured sequences $9 \quad$ was at least 0.99 .

12 2.4 Determination of mRNA and protein level of CerSs in cells

13 The mRNA was isolated using an RNA isolation kit (Qiagen, Hilden, Germany) according to the 14 manufacturer's instructions. cDNA synthesis from $200 \mathrm{ng}$ mRNA was performed using random 15 hexamers of the verso cDNA Kit (Thermo Scientific, Dreieich, Germany). The expression levels 16 of CerS1-6 and SPT were determined by Taqman $^{\mathrm{TM}}$ analysis using the SYBR Green Kit 17 (ABgene Limited, Epsom, United Kingdom) with an ABI Prism 7500 Sequence Detection 18 System (Applied Biosystems, Austin, USA). Relative expression of SPTLC2 and CerS family 19 genes was determined using the comparative CT (cycle threshold) method, normalizing relative 20 values to the expression level of $B$-actin as a housekeeping gene. The designed primer sets were 21 published previously [20]. Linearity of the assays was determined by serial dilutions of the 22 templates for each primer set separately. For western blot analysis the CerS2, CerS6 and HSP90 23 antibody were purchased from Santa Cruz (Heidelberg, Germany), Sigma Aldrich (Schnelldorf, 24 Germany) and BD Bioscience (Heidelberg, Germany), respectively. CerS2 and CerS6 antibodies 
1 were diluted 1:200 and incubated over night, while the HSP90 antibody was diluted 1:1000 and

2 incubated for 90 minutes. After washing, the blots were incubated with IRDye 680 conjugated

3 goat anti-rabbit $\operatorname{IgG}(\mathrm{H}+\mathrm{L})$ or IRDye $800 \mathrm{CW}$ conjugated goat anti-mouse $\operatorname{IgG}(\mathrm{H}+\mathrm{L})$ secondary

4 antibodies purchased from LI-COR (Bad Homburg, Germany). Membranes were analyzed on the

5 Odyssey infrared scanner from LI-COR (Bad Homburg, Germany).

$8 \quad 2.5$ Silencing of CerS with siRNA

$92.5 \times 10^{5}$ HCT-116 cells were transfected with 100 pmol CerS2 siRNA/CerS4 siRNA/CerS5 10 siRNA, 150 pmol CerS6 siRNA or 100 pmol scrambled siRNA as control. siPort Amine 11 (Ambion, Darmstadt, Germany) was used for transfection according to the manufacturer`s 12 protocol. Briefly, Opti-MEM medium with transfection reagent were incubated for $10 \mathrm{~min}$ at RT, 13 than added to the siRNA solution consisting of Opti-MEM medium and siRNA, followed by an 14 incubation for $10 \mathrm{~min}$ at RT. $2.5 \times 10^{5} \mathrm{HCT}-116$ cells were incubated with siRNA transfection 15 solution, and the process was repeated after $24 \mathrm{~h}$. After $41 \mathrm{~h}$ the transfected HCT-116 cells were 16 either harvested for mRNA isolation (RNA isolation kit (Qiagen, Hilden, Germany)) or treated 17 with DMSO or $50 \mu \mathrm{M}$ celecoxib and subjected to sphingolipid analysis. The effectiveness of the 18 siRNA knock-down was verified using quantitative PCR.

212.6 Nude mice experiment

22 In a previous study we demonstrated that celecoxib exhibit also in vivo its antiproliferative 23 effects using the nude mouse model [21]. For the current study brain, heart, lung, liver, small 24 intestine, large intestine, kidney, testes and tumor tissue from these mice were extracted and 
1 washed with $0.9 \%$ saline and frozen by $-80^{\circ} \mathrm{C}$. In all experiments, the ethics guidelines for 2 investigations in conscious animals were obeyed and the local Ethics Committee for Animal 3 Research approved the experiments.

$6 \quad 2.7$ In vitro cell viability assay

7 The WST-1 assay (Roche Diagnostic GmbH, Mannheim) was used to determine the viability and 8 proliferation rate of the cells after treatment with CerS6 siRNA and celecoxib or DMSO. The 9 cells were treated with $62.5 \mathrm{nMol}$ CerS6 siRNA or $62.5 \mathrm{nMol}$ scrambled siRNA for $41 \mathrm{~h}$. 10 Subsequently, the cells were treated either with $50 \mu \mathrm{M}$ celecoxib or DMSO. After $20 \mathrm{~h}$ of 11 incubation $10 \mu \mathrm{l}$ of WST-1 reagent were added to each well and the cells were incubated for 12 further $90 \mathrm{~min}$. The formation of the dye was measured at $450 \mathrm{~nm}$ against a reference wavelength 13 of $620 \mathrm{~nm}$ using a 96-well spectrophotometric plate reader (SPECTRAFlour Plus, Tecan, 14 Crailsheim, Germany). For the calculation of the cell viability the DMSO treated cells were used 15 as the $100 \%$ value.

$18 \quad 2.8$ Statistics

19 Ceramide levels, palmitoyl-CoA levels and mRNA expression data are presented as a mean \pm 20 s.e.m (standard error of the mean). Ceramide data and mRNA expression data of the cell culture 21 experiments were analyzed using an independent t-test and the confidence interval was set at $2295 \%$. Ceramide data of the nude mice experiments were analyzed using an independent $t$-test and 23 the confidence interval was set at 95\%, while the variances were assumed as not equal. The SPSS 249.01 software was used for statistical analyses. 
$4 \quad 3.1$ Time dependent alteration of ceramide levels in HCT-116 cells after treatment with celecoxib

5 We recently published that celecoxib inhibits the (dihydro)ceramide desaturase causing an

6 increase of $\mathrm{C}_{16: 0^{-}}, \mathrm{C}_{24: 1^{-}}, \mathrm{C}_{24: 0^{-}}$-dihydroceramide and a decrease of $\mathrm{C}_{24: 1^{-}}$and $\mathrm{C}_{24: 0^{-} \text {-ceramide. }}$

7 Interestingly, the amount of $\mathrm{C}_{16: 0}$-ceramide remained unaltered in that study after $2 \mathrm{~h}$ of celecoxib

$8(80 \mu \mathrm{M})$ treatment. However, the total ceramide level (includes $\mathrm{C}_{16: 0^{-}}, \mathrm{C}_{24: 1^{-}}, \mathrm{C}_{24: 0^{-}}$

9 dihydroceramide and ceramides) doubled relative to the control [18]. In this former study, we

10 investigated shorter time periods with higher celecoxib concentrations $(80 \mu \mathrm{M})$ since celecoxib

11 exhibits an $\mathrm{IC}_{50}$ value of $79 \pm 2 \mu \mathrm{M}$ for the (dihydro)ceramide desaturase. For the present study,

12 a concentration of $50 \mu \mathrm{M}$ celecoxib was applied to minimize the influence of (dihydro)ceramide

13 desaturase inhibition by celecoxib. Since the present study focused on the mechanism of

14 sphingolipid pathway induction by celecoxib, HCT-116 cells were treated in a time dependent

15 fashion up to $20 \mathrm{~h}$ with $50 \mu \mathrm{M}$ celecoxib or DMSO (vehicle control). Ceramide concentrations

16 were determined by LC-MS/MS. The treatment of HCT-116 cells with celecoxib time-

17 dependently and significantly increased the amounts of $\mathrm{C}_{16: 0}$-dhCer, $\mathrm{C}_{24: 1}$-dhCer, $\mathrm{C}_{24: 0}$-dhCer, 18 sphinganine and sphingosine as well as $\mathrm{C}_{14: 0}$-Cer, $\mathrm{C}_{16: 0^{-}}$Cer and $\mathrm{C}_{18: 0}$-Cer (figure 1B, data are 19 only partly shown). Instead, the ceramides $\mathrm{C}_{20: 0^{-}}, \mathrm{C}_{24: 1^{-}}$and $\mathrm{C}_{24: 0^{-}}$-ceramide decreased time20 dependently (figure $1 \mathrm{~B})$. All in all, the total ceramide levels (including dihydroceramides $\left(\mathrm{C}_{16: 0^{-}}\right.$ $\left.21 \mathrm{C}_{24: 0}\right)$, ceramides $\left(\mathrm{C}_{14: 0}-\mathrm{C}_{24: 0}\right)$, sphingosine, sphinganine) increased by up to $210 \pm 30 \%$ after 22 incubation with $50 \mu \mathrm{M}$ celecoxib for $6 \mathrm{~h}$ as compared to cells treated with DMSO. 
13.2 mRNA and protein expression of CerSs and SPT in HCT-116 cells after celecoxib treatment

2 The observed increase of $\mathrm{C}_{14: 0}-\mathrm{Cer}, \mathrm{C}_{16: 0}$-Cer and $\mathrm{C}_{18: 0}$-Cer could may be a consequence of 3 induction of the key enzymes of the sphingolipid pathway CerSs and/or SPT (figure 1A). 4 Therefore, we analyzed the expression level of CerSs and SPT by quantitative real time PCR and 5 by western blot analysis. In HCT-116 cells, CerS2 may be the predominant isoform while CerS4, 6 CerS5 and CerS6 are six fold less expressed (figure 2A). Experimentally, the expression level of 7 CerS1 and CerS3 was below the limit of detection (data not shown). HCT-116 cells were 8 incubated either with $50 \mu \mathrm{M}$ celecoxib or with DMSO (control) for the indicated time periods. 9 Our data exhibit that the mRNA expression of CerS2, which is specific for the synthesis of 10 longer ceramides like $\mathrm{C}_{24: 1^{-}}$and $\mathrm{C}_{24: 0^{-}}$Cer (see figure 5B, and [4]), significantly increased after 11 celecoxib treatment whereas the expression levels of CerS4, CerS5 didn't change. mRNA levels 12 of CerS6 and SPTLC2 slightly but significantly increased after 4h and decreased after $16 \mathrm{~h}$ of 13 treatment with celecoxib as compared to the respective control. These results are unexpected due 14 to literature reports [4] and our own CerS6 knock down experiments (see figure 5B) indicating 15 that CerS6 is specific for the synthesis of short ceramides like $\mathrm{C}_{16: 0}$-Cer. Since the mRNA levels 16 of CerS2 and CerS6 are slightly increased after celecoxib treatment, we checked the influence of 17 celecoxib on protein levels of CerS2 and CerS6. HCT-116 cells were time dependently incubated 18 with $50 \mu \mathrm{M}$ celecoxib or with DMSO (control). As shown in figure $2 \mathrm{~B}$ celecoxib has no 19 influence on the protein amounts of CerS2 or CerS6.

$22 \quad 3.3$ Ceramide synthase activity

23 As the increase of $\mathrm{C}_{16: 0}$-Cer after celecoxib treatment was most pronounced we focused in the 24 following on this ceramide species. Our RNA and protein data suppose that the increase in $\mathrm{C}_{16: 0^{-}}$ 
1 Cer is not to be due to an upregulation of CerS6, therefore we investigated the ability of

2 celecoxib to activate CerSs. Unfortunately, an activity assay using the microsomal fraction of

3 HCT-116 cells showed no activation of CerSs by celecoxib treatment [18]. The same

4 experiments also revealed that inhibition of the (dihydro)ceramide desaturase after celecoxib

5 treatment was only detectable in living cells. Therefore, we developed a cell-based assay to

6 detect the influence of celecoxib on ceramide synthase activity. In this assay, exogenously added

7 sphingosine $\left(\mathrm{C}_{17}\right)$ functioned as substrate that is transformed to ceramides $\left(\mathrm{C}_{17}\right)$ by the action of

8 the various ceramide synthases. The usage of sphingosine effectively excludes the participation

9 of (dihydro)ceramide desaturase, which is responsible for the generation of ceramide from 10 dihydroceramide if sphinganine (dihydro-sphingosine) is the substrate (see figure 1A). With the 11 use of sphingosine $\left(\mathrm{C}_{17}\right)$, leading to the formation of ceramide $\left(\mathrm{C}_{17}\right)$, we could discriminate 12 between endogenous ceramide $\left(\mathrm{C}_{18}\right)$ and the newly synthesized ceramide $\left(\mathrm{C}_{17}\right)$. Furthermore, 13 HCT-116 cells were incubated with $150 \mathrm{nM}$ myriocin, an inhibitor of the SPT, to block the 14 endogenous sphinganine synthesis to reduce the natural substrate of the CerSs [18]. Inhibition of 15 SPT does not influence the amounts of palmitoyl-CoA, a precursor of de novo sphingolipid 16 synthesis (data not shown). HCT-116 cells were either incubated for $2 \mathrm{~h}$ with DMSO/5 $\mu \mathrm{M}$ 17 sphingosine $\left(\mathrm{C}_{17}\right) / 150 \quad \mathrm{nM}$ myriocin (control) or with $50 \quad \mu \mathrm{M}$ celecoxib/5 $\mu \mathrm{M}$ 18 sphingosine $\left(\mathrm{C}_{17}\right) / 150 \mathrm{nM}$ myriocin (figure 3A). Following the incubation, sphingolipids were 19 extracted and measured by LC-MS/MS. The levels of the different ceramide $\left(\mathrm{C}_{17}\right)$ species in 20 control cells were set at $100 \%$. The amounts of ceramide $\left(\mathrm{C}_{17}\right)$ species in cells treated with 21 celecoxib were scaled to the control levels. Celecoxib treatment led to an increase of $\mathrm{C}_{16: 0^{-}}$ $22 \operatorname{Cer}\left(\mathrm{C}_{17}\right)$ by $280 \%$, and of $\mathrm{C}_{14: 0}-\operatorname{Cer}\left(\mathrm{C}_{17}\right)$ by $123 \%$, while the other ceramides $\left(\mathrm{C}_{18: 0^{-}}-\operatorname{Cer}\left(\mathrm{C}_{17}\right)\right.$, $\left.23 \mathrm{C}_{20: 0^{-}}-\operatorname{Cer}\left(\mathrm{C}_{17}\right), \mathrm{C}_{22: 0^{-}} \operatorname{Cer}\left(\mathrm{C}_{17}\right), \mathrm{C}_{24: 1}-\operatorname{Cer}\left(\mathrm{C}_{17}\right), \mathrm{C}_{24: 0^{-}}-\operatorname{Cer}\left(\mathrm{C}_{17}\right), \mathrm{C}_{26: 0^{-}}-\operatorname{Cer}\left(\mathrm{C}_{17}\right)\right)$ decreased. The 
1 increase of $\mathrm{C}_{16: 0}-$ Cer occurs time dependently and starts after treatment of cells with celecoxib 2 for $2 \mathrm{~h}$ (figure $3 \mathrm{~B}$ ).

3

4

$5 \quad 3.4$ Celecoxib did not increase the palmitoyl-CoA level

6 Palmitoyl-CoA, in addition to sphingosine, is essential for the synthesis of $\mathrm{C}_{16: 0}$-Cer by the 7 (dihydro)ceramide synthase. Addition of exogenous palmitoyl-CoA predominantly led to an 8 increase of $\mathrm{C}_{16: 0}$-Cer (data not shown). To investigate whether or not celecoxib treatment leads to 9 an increase of palmitoyl-CoA, which could in turn activate the (dihydro)ceramide synthase, we 10 measured the amount of palmitoyl-CoA in celecoxib treated HCT-116 cells using LC-MS/MS. 11 As shown in figure 4, palmitoyl-CoA amounts time-dependently decreased within $2 \mathrm{~h}$. The 12 decrease was more pronounced in cells treated with $50 \mu \mathrm{M}$ celecoxib than in control cells. The 13 decrease of palmitoyl-CoA in untreated and celecoxib treated cells could be due to an increase of 14 ceramides (data not shown) induced either by celecoxib (see above) or by growth activation due 15 to growth factors in fresh media.

183.5 Ceramide synthase 6 is involved in $\mathrm{C}_{16: 0}$-Cer synthesis in HCT-116 cells

19 Subsequently, we addressed the question whether or not celecoxib activates a specific CerS in 20 HCT-116 cells. Therefore, we performed silencing experiments using siRNA for CerS2, CerS4, 21 CerS5, and CerS6. HCT-116 cells were either untreated (control) or treated with scrambled 22 siRNA, or the respective siRNAs for the various CerSs for $41 \mathrm{~h}$. The mRNA expression was 23 determined using relative quantitative PCR. The mRNA expression of the various CerSs was 24 normalized to GAPDH and scaled to untreated cells. Scrambled siRNA (unspecific siRNA) led 
1 to a slight increase of the expression of all ceramide synthases as compared to untreated cells

2 (figure 5A). The mRNA expression of CerS2, CerS4, CerS5 and CerS6 were reduced to $13 \%$, $325 \%, 32 \%, 27 \%$, respectively, by their specific siRNAs (figure 5A). The various siRNAs were

4 specific, as demonstrated by the lack of significant cross regulation to other CerSs (data not 5 shown). Furthermore, none of the various siRNAs altered the mRNA expression of B-Actin 6 which was used as control (figure 5A). These results confirm the specificity of the CerS siRNAs 7 to down-regulate their specific endogenous targets. To determine whether or not decreased 8 mRNA expression levels affect the ceramide levels, we measured the ceramide levels after $41 \mathrm{~h}$ 9 treatment with the various siRNAs. Silencing of CerS2 decreased the synthesis of $\mathrm{C}_{24: 1}-\mathrm{Cer} / \mathrm{C}_{24: 0^{-}}$ 10 Cer, silencing of CerS4 slightly decreased the synthesis of $\mathrm{C}_{16: 0^{-}}$Cer/ $\mathrm{C}_{24: 1}-\mathrm{Cer} / \mathrm{C}_{24: 0}$-Cer and 11 silencing of CerS6 significantly decreased the synthesis of $\mathrm{C}_{16: 0}$-Cer. Silencing of CerS5 had no 12 effect on the predominantly synthesized ceramides (figure 5B). These data indicate that CerS6 is 13 predominantly responsible for the synthesis of $\mathrm{C}_{16: 0}$-Cer. Therefore, we investigated, whether or 14 not silencing of CerS6 by siRNA could also prevent the induction of $\mathrm{C}_{16: 0}$-Cer production in 15 HCT-116 cells after celecoxib treatment. HCT-116 cells were pretreated with siRNA against 16 CerS6. Afterwards, the cells were incubated with $150 \mathrm{nM}$ myriocin, to inhibit sphingolipid de

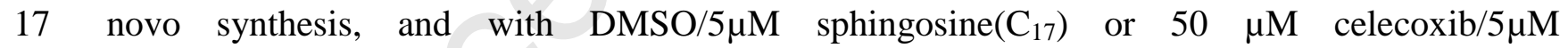
18 sphingosine $\left(\mathrm{C}_{17}\right)$ for $2 \mathrm{~h}$. Treatment of cells with siRNA against CerS6 completely prevented the 19 celecoxib induced increase of $\mathrm{C}_{16: 0}-\operatorname{Cer}\left({ }_{17}\right)$ in $\mathrm{HCT}-116$ cells (figure 5C). In contrast, CerS2, 20 CerS4 and CerS5 silencing in HCT-116 cells exhibited only a slight decrease in $\mathrm{C}_{16: 0}-\mathrm{Cer}\left(\mathrm{C}_{17}\right)$ 21 synthesis induced by celecoxib. In conclusion both the cell based activity assay as well as the 22 ceramide expression pattern after silencing various CerSs points to CerS6 as a target of 23 celecoxib. 


\subsection{Celecoxib activates the salvage pathway}

3 Ceramides are either synthesized via a salvage pathway or de novo synthesis. Since ceramide 4 synthases play an essential role in both pathways, we investigated which pathway is activated by 5 celecoxib. For this purpose, an inhibitor of the L-serine palmitoyl transferase (myriocin) was 6 used, which only blocks the de novo synthesis. In contrast, the non-selective ceramide synthase 7 inhibitor fumonisin B1 (FB1) blocks both the salvage pathway and the de novo synthesis of 8 ceramides. HCT-116 cells were incubated with either DMSO (control), $50 \mu \mathrm{M}$ celecoxib, $70 \mu \mathrm{M}$ 9 FB1, $150 \mathrm{nM}$ myriocin or co-treated with a mixture of $50 \mu \mathrm{M}$ celecoxib/70 $\mu \mathrm{M}$ FB1 or $50 \mu \mathrm{M}$ 10 celecoxib/150 nM myriocin for $6 \mathrm{~h}$. In Fig. 6A we were able to show that myriocin alone reduces 11 the $\mathrm{C}_{16: 0}$-Cer levels below the control levels (dark grey bar). In comparison, treatment of cells 12 with $50 \mu \mathrm{M}$ celecoxib and myriocin (striped, dark grey bar) reduces the ceramide levels 13 approximately to control (white bar), but as compared to the myriocin treated cells (dark grey 14 bar), the inhibition is not complete. Instead, fumonisin B1 inhibits ceramide production nearly to 15 the same extend in control cells as well as in celecoxib treated cells. The difference in $\mathrm{C}_{16: 0}-\mathrm{Cer}$ 16 levels between celecoxib/fumonisin B1 treated cells and cells treated with celecoxib/myriocin 17 may be due to the ceramide synthesized by the salvage pathway. Desipramine induces the 18 degradation of the acid sphingomyelinase and the down-regulation of acid ceramidase [22] 19 leading to a partial inhibition of the salvage pathway (figure 1A). HCT-116 cells were incubated 20 with either DMSO (control), $50 \mu \mathrm{M}$ celecoxib, $20 \mu \mathrm{M}$ desipramine or co-treated with a mixture 21 of $50 \mu \mathrm{M}$ celecoxib/20 $\mu \mathrm{M}$ desipramine $6 \mathrm{~h}$. Fig $6 \mathrm{C}$ shows that treatment of control cells with 22 desipramine alone has only a slight effect on $\mathrm{C}_{16: 0}$-Cer levels, indicating that the 23 sphingomyelinase pathway plays only a minor role for the synthesis of $\mathrm{C}_{16: 0}$-Cer in control cells. 24 In contrast, desipramine completely prevents the increase of ceramide induced by celecoxib 
1 treatment. These data point out that after celecoxib treatment the de novo synthesis plays only a

2 minor role for the production of $\mathrm{C}_{16: 0}$-Cer whereas the salvage pathway seems to have a more

3 important role. Treatment of HCT-116 cells with celecoxib significantly increased the amount of

4 sphingosine, which is a key precursor of the salvage pathway (see figure 1A, figure 6B). $20 \mu \mathrm{M}$

5 desipramine reduced the sphingosine level in control cells and completely prevented an increase

6 of sphingosine after celecoxib treatment (Fig 6B). These data indicate that celecoxib treatment

7 lead to an activation of the salvage pathway in HCT-116 cells.

$10 \quad 3.7$ Celecoxib specifically increases $\mathrm{C}_{16: 0}$-Cer in nude mice tissue

11 In order to support the results obtained in vitro, nude mice were used to generate in vivo data. We 12 demonstrated in a previous study that celecoxib inhibits the tumor growth of HCT-116 13 xenografts in nude mice [21]. Nude mice were treated for three weeks with $10 \mathrm{mg} / \mathrm{kg}$ celecoxib 14 or with vehicle. For further analysis, the brain, lung, heart, stomach, large intestine, small 15 intestine, testes and the tumor tissues were extracted. The tissues were homogenized and the 16 sphingolipids were extracted and determined by LC-MS/MS. In line with the in vitro data, 17 celecoxib treatment significantly increased the level of $\mathrm{C}_{16: 0^{-}}$Cer in stomach, small intestine and 18 tumor tissue of the nude mice (figure 7). No differences were detectable in the other tissues 19 investigated. Interestingly, no changes were observed after celecoxib treatment for $\mathrm{C}_{24: 1}$-Cer and $20 \quad \mathrm{C}_{24: 0}$-Cer.

$23 \quad 3.8$ Silencing of CerS6 protects cells against the anti-profliferative effect of celecoxib 
1 Next we checked, whether the increased $\mathrm{C}_{16: 0}$-Cer level could be at least in part responsible for

2 the observed toxic effects of celecoxib. For this purpose we silenced the CerS6 expression

3 transiently in HCT-116 cells and compared the toxic effects of celecoxib with control HCT-116

4 cells. Treatment of HCT-116 cells with $50 \mu \mathrm{M}$ celecoxib for $24 \mathrm{~h}$ reduced the viability of control

5 cells about $24 \%$ and only about $8 \%$ in CerS6 silenced cells (figure 8). These data indicate that

6 activation of CerS6 and therefore an increase in $\mathrm{C}_{16: 0}$ Cer is important for the toxic effect of 7 celecoxib.

\section{Discussion}

13 Investigations about the "specialization" of ceramides, especially their specific synthesis and 14 their sophisticated role in cell regulation are currently a hot topic of research. To date, few 15 reports describe the differential regulation of ceramides with various chain-lengths. As data 16 accumulate, it is becoming increasingly apparent that the chain length, subcellular location and 17 the biosynthetic pathway (salvage or de novo) of ceramides all contribute to physiological and 18 pathophysiological regulatory mechanisms in the cell [11]. Moreover, there are various proteins 19 that can recognize ceramides with a high degree of fatty acid chain length specificity, such as the 20 ceramide transport protein CERT (preference for $\mathrm{C}_{16: 0}$-Cer/ $\mathrm{C}_{18: 0}-\mathrm{Cer}$ ) [23] and the inhibitor 2 of 21 protein phosphatase $2 \mathrm{~A}$ (preference for $\mathrm{C}_{18: 0}$-Cer) [24].

22 Celecoxib induces a significant increase of $\mathrm{C}_{16: 0}$-Cer in vitro in $\mathrm{HCT}-116$ colon carcinoma cells 23 as well as in vivo in nude mouse tissues, the stomach, the small intestine and tumor tissues. This 24 elevation was attributed to an elevated enzymatic activity of CerS6 and not to transcriptional 
1 upregulation of CerS6. In another study we could show that only the overexpression of CerS6 in

2 HCT-116 cells led to an increase of $\mathrm{C}_{16: 0}$-Cer (unpublished data). Furthermore, we demonstrated

3 that celecoxib activates predominantly the salvage pathway, as inhibition of the de novo

4 synthesis by L-serine palmitoyl transferase inhibitor only slightly prevents the increase of $\mathrm{C}_{16: 0^{-}}$

5 Cer amounts, while inhibition of CerSs by fumonisin B1 blocks more effective the increase of

$6 \mathrm{C}_{16: 0}$-Cer amounts. Apart from inhibiting $\mathrm{N}$-acylation of sphinganine, which occurs downstream

7 of the SPT, fumonisin B1 also blocks the reacylation of sphingosine produced by the salvage

8 pathway (see also figure 1A). Nevertheless, both, the increase of the mRNA level of SPT and of

9 sphinganine followed by treatment with celecoxib as well as the effectiveness of myriocin

10 suggest that also the de novo synthesis is involved. Interestingly, the endocannabinoid analog

$11 \mathrm{R}(+)$-methanandamide increased the ceramide level in neuroglioma cells by activating the

12 ceramide synthases of the salvage pathway but not of de novo synthesis, since the ceramide

13 upregulation was prevented by fumonisin B1 but not by myriocin [25]. Furthermore,

14 desipramine, blocking the degradation of sphingomyeline to ceramide by aSMase, which is one

15 resource of sphingosine, completely prevented the increase of sphingosine and $\mathrm{C}_{16: 0}$-Cer after

16 celecoxib treatment.

17 In a previous study we could show that myriocin prevents, at least partially, celecoxib-induced

18 growth inhibition as well as apoptosis [18]. With the data presented here, we could demonstrate

19 that the salvage pathway and CerS6 are targets of celecoxib. Silencing of CerS6 significantly

20 reduced celecoxib-induced growth-inhibition (figure 8), suggesting that specific activation of this

21 ceramide synthase and thereby accumulation of $\mathrm{C}_{16: 0}$-Cer contributes to the toxic effects of 22 celecoxib. The role of $\mathrm{C}_{16: 0}$-Cer and other ceramides in cancer development are actually highly

23 debated. In this regard White-Gilbertson et al. reported that TRAIL-(tumor necrosis factor-

24 related apoptosis-inducing ligand-) induced apoptosis depends on activation of CerS6 and 
1 synthesis of $\mathrm{C}_{16: 0}$-Cer [26]. Moreover, irradiation treatment of Molt-4 leukemia cells led to a p53

2 dependent synthesis of $\mathrm{C}_{16: 0}$-Cer through a transcriptional upregulation of CerS5 [27].

3 Furthermore not only the increase or decrease of one specific ceramide could be involved in

4 tumor development but also an altered ratio of the ceramides. Liu et al. [28] postulated that the

5 altered ratio of $\mathrm{C}_{16: 0}-\mathrm{Cer} / \mathrm{C}_{24: 0}-\mathrm{Cer}$ is responsible for the induction of apoptosis. The observation

6 that an increase in the ratio of $\mathrm{C}_{16: 0^{-}} \mathrm{Cer} / \mathrm{C}_{24: 0}$-Cer from 1.28 in untreated cells to 3.09 in

7 celecoxib-treated $(50 \mu \mathrm{M}, 6 \mathrm{~h})$ cells supports the notion that the ratio $\mathrm{C}_{16: 0}-\mathrm{Cer} / \mathrm{C}_{24: 0}-\mathrm{Cer}$ is 8 critical.

9 But our data raises another important question: how does celecoxib selectively activate one 10 specific ceramide synthase? Ceramide synthases are located at the endoplasmic reticulum, where 11 the de novo synthesis occurs [29] and at mitochondria-associated membranes [30]. However, 12 whether these enzymes are also involved in de novo synthesis or whether they only play a role in 13 the salvage pathway is not clear. Interestingly, a previous study revealed that during cerebral 14 ischemia/reperfusion mitochondrial ceramide levels are elevated due to the activation of 15 mitochondrial ceramide synthases by post-translational mechanisms [31]. Interestingly, in mouse 16 brain only CerS1, CerS2 and CerS6 are located in the mitochondrial membrane, while CerS5 is 17 located in the endoplasmic reticulum [31]. Such specific localizations could be the rationale for 18 the specific activation of CerS6 in HCT-116 cells by celecoxib. The activation of CerS6 after 19 celecoxib treatment is only observable in living cells with intact membrane structures. Recently, 20 we showed that celecoxib accumulates specifically in cellular membranes [32]. This 21 accumulation of celecoxib may explain why we only observed an activation of CerS6 in viable 22 cells. Furthermore, activation of an enzyme may depend on post-translational modifications as 23 well as co-factor and substrate availability. An increase in substrate availability could be 24 excluded in these experiments, because celecoxib does not raise the palmitoyl-CoA 
1 concentration. Beside of a direct mechanism, several possibilities for an indirect activation exist:

2 1) Alterations in the quaternary structure of the CerSs. Koyanagi et al. linked already augmented

3 levels of dihydroceramide and ceramide in tumor tissue to CerSs with a larger than normal

4 molecular mass [33]. 2) Translocation processes of the CerSs. Cisplatin induces rapid

5 translocation of CerS1 but not CerS4 or CerS5 from ER to Golgi apparatus [7]. 3)

6 Phosphorylation of the CerSs. Using the SWISS_Prot data bank we found several potential

7 phosphorylation sides in the CerS6 protein sequence. But whether one of these mechanisms

8 contributes to the effect observed after celecoxib treatment requires further investigations.

9 In conclusion, our data clearly demonstrate that celecoxib activates CerS6 and thereby causes an 10 increase of $\mathrm{C}_{16: 0}$-Cer level, which, in turn, contributes to the toxic effects of celecoxib. The 11 influence of celecoxib on the sphingolipid pathway might be of great clinical relevance. On the 12 one hand celecoxib is used in clinical trials for cancer treatment regimes. On the other hand 13 celecoxib is investigated for usability against Alzheimer disease [34]. Progression of this disease 14 is positively correlated with ceramide levels [35].

\section{ACKNOLEDGEMENTS}

The authors thank Dr. Wesley McGinn-Straub for the linguistic revision of the manuscript. This

TP5 (GR2011/2-1) and the LOEWE Lipid Signaling Forschungszentrum Frankfurt (LiFF).

\section{REFERENCES}


1. Ogretmen B and Hannun YA, Biologically active sphingolipids in cancer pathogenesis

2. Pewzner-Jung Y, Ben-Dor S and Futerman AH, When do Lasses (longevity assurance genes) become CerS (ceramide synthases)?: Insights into the regulation of ceramide synthesis. J Biol Chem 281(35): 25001-5, 2006.

3. Rabionet M, van der Spoel AC, Chuang CC, von Tumpling-Radosta B, Litjens M, Bouwmeester D, Hellbusch CC, Korner C, Wiegandt H, Gorgas K, Platt FM, Grone HJ and Sandhoff R, Male germ cells require polyenoic sphingolipids with complex glycosylation for completion of meiosis: a link to ceramide synthase-3. J Biol Chem 283(19): 13357-69, 2008.

4. Mizutani Y, Kihara A and Igarashi Y, Mammalian Lass6 and its related family members regulate synthesis of specific ceramides. Biochem J 390(Pt 1): 263-71, 2005.

5. Riebeling C, Allegood JC, Wang E, Merrill AH, Jr. and Futerman AH, Two mammalian longevity assurance gene (LAG1) family members, trh1 and trh4, regulate dihydroceramide synthesis using different fatty acyl-CoA donors. J Biol Chem 278(44): 43452-9, 2003.

6. Laviad EL, Albee L, Pankova-Kholmyansky I, Epstein S, Park H, Merrill AH, Jr. and Futerman AH, Characterization of ceramide synthase 2: tissue distribution, substrate specificity, and inhibition by sphingosine 1-phosphate. J Biol Chem 283(9): 5677-84, 2008.

7. Min J, Mesika A, Sivaguru M, Van Veldhoven PP, Alexander H, Futerman AH and Alexander S, (Dihydro)ceramide synthase 1 regulated sensitivity to cisplatin is associated with the activation of p38 mitogen-activated protein kinase and is abrogated by sphingosine kinase 1. Mol Cancer Res 5(8): 801-12, 2007.

8. Ruvolo PP, Intracellular signal transduction pathways activated by ceramide and its metabolites. Pharmacol Res 47(5): 383-92, 2003.

9. Perry DK, Carton J, Shah AK, Meredith F, Uhlinger DJ and Hannun YA, Serine palmitoyltransferase regulates de novo ceramide generation during etoposide-induced apoptosis. J Biol Chem 275(12): 9078-84, 2000.

10. Charles AG, Han TY, Liu YY, Hansen N, Giuliano AE and Cabot MC, Taxol-induced ceramide generation and apoptosis in human breast cancer cells. Cancer Chemother Pharmacol 47(5): 444-50, 2001.

11. Modrak DE, Gold DV and Goldenberg DM, Sphingolipid targets in cancer therapy. Mol Cancer Ther 5(2): 200-8, 2006.

12. Guenther GG, Peralta ER, Rosales KR, Wong SY, Siskind LJ and Edinger AL, Ceramide starves cells to death by downregulating nutrient transporter proteins. Proc Natl Acad Sci U S A 105(45): 17402-7, 2008.

13. Selzner M, Bielawska A, Morse MA, Rudiger HA, Sindram D, Hannun YA and Clavien PA, Induction of apoptotic cell death and prevention of tumor growth by ceramide analogues in metastatic human colon cancer. Cancer Res 61(3): 1233-40, 2001.

14. Koki AT and Masferrer JL, Celecoxib: a specific COX-2 inhibitor with anticancer properties. Cancer Control 9(2 Suppl): 28-35, 2002.

15. Steinbach G, Lynch PM, Phillips RK, Wallace MH, Hawk E, Gordon GB, Wakabayashi N, Saunders B, Shen Y, Fujimura T, Su LK and Levin B, The effect of celecoxib, a 
cyclooxygenase-2 inhibitor, in familial adenomatous polyposis. $N$ Engl J Med 342(26): 1946-52, 2000.

16. Grosch S, Maier TJ, Schiffmann S and Geisslinger G, Cyclooxygenase-2 (COX-2)independent anticarcinogenic effects of selective COX-2 inhibitors. J Natl Cancer Inst 98(11): 736-47, 2006.

17. Maier TJ, Tausch L, Hoernig M, Coste O, Schmidt R, Angioni C, Metzner J, Groesch S, Pergola C, Steinhilber D, Werz O and Geisslinger G, Celecoxib inhibits 5-lipoxygenase. Biochem Pharmacol 76(7): 862-72, 2008.

18. Schiffmann S, Sandner J, Schmidt R, Birod K, Wobst I, Schmidt H, Angioni C, Geisslinger $\mathrm{G}$ and Grosch S, The selective COX-2 inhibitor celecoxib modulates sphingolipid synthesis. J Lipid Res 50(1): 32-40, 2009.

19. Brautigam L, Vetter G, Tegeder I, Heinkele G and Geisslinger G, Determination of celecoxib in human plasma and rat microdialysis samples by liquid chromatography tandem mass spectrometry. J Chromatogr B Biomed Sci Appl 761(2): 203-12., 2001.

20. Schiffmann S, Sandner J, Birod K, Wobst I, Angioni C, Ruckhaberle E, Kaufmann M, Ackermann H, Lotsch J, Schmidt H, Geisslinger G and Grosch S, Ceramide synthases and ceramide levels are increased in breast cancer tissue. Carcinogenesis 30(5): 745-52, 2009.

21. Schiffmann S, Maier TJ, Wobst I, Janssen A, Corban-Wilhelm H, Angioni C, Geisslinger $\mathrm{G}$ and Grosch $\mathrm{S}$, The anti-proliferative potency of celecoxib is not a class effect of coxibs. Biochem Pharmacol 76(2): 179-87, 2008.

22. Elojeimy S, Holman DH, Liu X, El-Zawahry A, Villani M, Cheng JC, Mahdy A, Zeidan Y, Bielwaska A, Hannun YA and Norris JS, New insights on the use of desipramine as an inhibitor for acid ceramidase. FEBS Lett 580(19): 4751-6, 2006.

23. Kudo N, Kumagai K, Tomishige N, Yamaji T, Wakatsuki S, Nishijima M, Hanada K and Kato R, Structural basis for specific lipid recognition by CERT responsible for nonvesicular trafficking of ceramide. Proc Natl Acad Sci U S A 105(2): 488-93, 2008.

24. Mukhopadhyay A, Saddoughi SA, Song P, Sultan I, Ponnusamy S, Senkal CE, Snook CF, Arnold HK, Sears RC, Hannun YA and Ogretmen B, Direct interaction between the inhibitor 2 and ceramide via sphingolipid-protein binding is involved in the regulation of protein phosphatase 2A activity and signaling. Faseb J, 2008.

25. Ramer R, Weinzierl U, Schwind B, Brune K and Hinz B, Ceramide is involved in $\mathrm{r}(+)-$ methanandamide-induced cyclooxygenase-2 expression in human neuroglioma cells. Mol Pharmacol 64(5): 1189-98, 2003.

26. White-Gilbertson S, Mullen T, Senkal C, Lu P, Ogretmen B, Obeid L and VoelkelJohnson C, Ceramide synthase 6 modulates TRAIL sensitivity and nuclear translocation of active caspase-3 in colon cancer cells. Oncogene 28(8): 1132-41, 2009.

27. Panjarian S, Kozhaya L, Arayssi S, Yehia M, Bielawski J, Bielawska A, Usta J, Hannun YA, Obeid LM and Dbaibo GS, De novo N-palmitoylsphingosine synthesis is the major biochemical mechanism of ceramide accumulation following p53 up-regulation. Prostaglandins Other Lipid Mediat 86(1-4): 41-8, 2008.

28. Liu X, Elojeimy S, Turner LS, Mahdy AE, Zeidan YH, Bielawska A, Bielawski J, Dong JY, El-Zawahry AM, Guo GW, Hannun YA, Holman DH, Rubinchik S, Szulc Z, Keane TE, Tavassoli M and Norris JS, Acid ceramidase inhibition: a novel target for cancer therapy. Front Biosci 13: 2293-8, 2008.

29. Futerman AH and Riezman H, The ins and outs of sphingolipid synthesis. Trends Cell Biol 15(6): 312-8, 2005. 
30. Bionda C, Portoukalian J, Schmitt D, Rodriguez-Lafrasse C and Ardail D, Subcellular compartmentalization of ceramide metabolism: MAM (mitochondria-associated membrane) and/or mitochondria? Biochem J 382(Pt 2): 527-33, 2004.

31. Yu J, Novgorodov SA, Chudakova D, Zhu H, Bielawska A, Bielawski J, Obeid LM, Kindy MS and Gudz TI, JNK3 signaling pathway activates ceramide synthase leading to mitochondrial dysfunction. J Biol Chem 282(35): 25940-9, 2007.

32. Maier TJ, Schiffmann S, Wobst I, Birod K, Angioni C, Hoffmann M, Lopez JJ, Glaubitz C, Steinhilber D, Geisslinger G and Grosch S, Cellular membranes function as a storage compartment for celecoxib. J Mol Med, 2009.

33. Koyanagi S, Kuga M, Soeda S, Hosoda Y, Yokomatsu T, Takechi H, Akiyama T, Shibuya S and Shimeno H, Elevation of de novo ceramide synthesis in tumor masses and the role of microsomal dihydroceramide synthase. Int J Cancer 105(1): 1-6, 2003.

34. Group AR, Lyketsos CG, Breitner JC, Green RC, Martin BK, Meinert C, Piantadosi S and Sabbagh M, Naproxen and celecoxib do not prevent AD in early results from a randomized controlled trial. Neurology 68(21): 1800-8, 2007.

35. Katsel P, Li C and Haroutunian V, Gene expression alterations in the sphingolipid metabolism pathways during progression of dementia and Alzheimer's disease: a shift toward ceramide accumulation at the earliest recognizable stages of Alzheimer's disease? Neurochem Res 32(4-5): 845-56, 2007. 


\section{LEGENDS}

4 Fig. 1A. Scheme of the sphingolipid de novo synthesis and the salvage pathway. SPT, L-serine 5 palmitoyltransferase; Myr, myriocin; CerS, (dihydro)ceramide synthase; FB1, fumonisin B1;

6 SMase, sphingomyelinase, Des, desipramine. B) Time-dependent alteration of the sphingolipid

7 level in HCT-116 cells treated with celecoxib. The cells were treated for various time points $(2 \mathrm{~h}$, $86 \mathrm{~h}, 8 \mathrm{~h}, 16 \mathrm{~h}, 20 \mathrm{~h}$ ) with $50 \mu \mathrm{M}$ celecoxib (light blue) or with DMSO (control, dark blue). The

9 ceramide levels were determined with LC-MS/MS and normalized to the number of treated cells. 10 Data are mean \pm s. e. $m$. of two independent experiments each achieved in triplicate. $*(p<0.05)$ $11{ }^{\circ}(\mathrm{p}<0.01)^{+}(\mathrm{p}<0.001)$ indicate significant difference between celecoxib and DMSO treated 12 cells at the various time points.

15 Fig. 2. The time-dependent effect of celecoxib both on the mRNA expression level and on the 16 protein level of ceramide synthases. HCT-116 cells were treated for various time points as 17 indicated with $50 \mu \mathrm{M}$ celecoxib or with DMSO (control). A) The relative mRNA expression of 18 CerS2, CerS4, CerS5, CerS6 and SPTLC2 were normalized to $\beta$-actin. The relative mRNA levels 19 were calculated with respect to control cells at the same time point. Data are mean $\pm \mathrm{s}$. e. m. of 20 one of two comparable independent experiments, each achieved in duplicate. B) Western blot 21 analysis of CerS2 and CerS6. As internal standard the heat shock protein HSP90 was used (one 22 of two independent experiments is shown). 
1 Fig. 3. Cell based ceramide synthase activity assay. HCT-116 cells were preincubated $90 \mathrm{~min}$

2 with $150 \mathrm{nM}$ myriocin and than co-treated either with $50 \mu \mathrm{M}$ celecoxib/5 $\mu \mathrm{M}$

3 sphingosine $\left(\mathrm{C}_{17}\right) / 150 \mathrm{nM}$ myriocin or with $\mathrm{DMSO} / 5 \mu \mathrm{M}$ sphingosine $\left(\mathrm{C}_{17}\right) / 150 \mathrm{nM}$ myriocin

4 (control) for $2 \mathrm{~h}$ (A) or various time points (B). The amounts of ceramide(C17) were determined

5 by LC-MS/MS. For analysis the area under the peak of the analyte was related to the area under

6 the peak of the internal standard. The relative increase of the specific ceramides was calculated 7 using the ratio analyte to internal standard of untreated cells as $100 \%$ value. The ceramide ratios 8 were normalized to the number of treated cells. Data are mean \pm s. e. m. of one of three 9 comparable independent experiments each achieved in duplicate.

12 Fig. 4. Celecoxib treatment reduces the palmitoyl-CoA level in HCT-116 cells. HCT-116 cells 13 were treated either with DMSO (white bars) or with $50 \mu \mathrm{M}$ celecoxib (black bars) for the 14 indicated time points. The palmitoyl-CoA levels were determined with LC-MS/MS and 15 normalized to the number of treated cells. Data are mean \pm s. e. m. of one of two comparable 16 independent experiments each achieved in triplicate. * $(\mathrm{p}<0.05) * *(\mathrm{p}<0.01)$ indicate 17 significant difference between celecoxib or DMSO treated cells at various time points and 18 untreated cells (time point $0 \mathrm{~h}$ ).

21 Fig. 5. Silencing of CerSs in HCT-116 cells using specific siRNAs. A) mRNA level in siRNA 22 treated HCT-116 cells. The cells were incubated $41 \mathrm{~h}$ with CerS2, CerS4, CerS5, CerS6 or 23 scrambled siRNA. The mRNA expression of CerS2, CerS4, CerS5 and CerS6 were normalized 24 to GAPDH. The relative mRNA expressions of the CerSs were calculated using cells treated only 
1 with transfection reagent as $100 \%$ value. As an additional control for the specificity of the

2 siRNA treatment we checked the mRNA expression of $\beta$-actin. As a representative experiment

3 the mRNA expression of $\beta$-actin after treatment with CerS4 siRNA is indicated. Data are mean \pm

4 s. e. m. of three independent experiments each achieved in triplicate. B) Ceramide levels in

5 siRNA (scrambled, CerS2, CerS4, CerS5, CerS6) treated HCT-116 cells. The ceramide levels

6 were determined using LC-MS/MS and were normalized to the number of treated cells. The

7 relative ceramide level was calculated using the ceramide level of HCT-116 cells treated with

8 scrambled siRNA as $100 \%$ value. Data are mean \pm s. e. m. of two independent experiments each

9 achieved in duplicate. $* *(\mathrm{p}<0.01)$ and $*(\mathrm{p}<0.05)$ indicate significant difference between CerS

10 siRNA treated and scrambled siRNA treated cells. C) Activity assay in siRNA treated HCT-116

11 cells. After 41 h treatment with siRNA (against CerS2, CerS4, CerS5, CerS6 or scrambled) HCT-

12116 cells were preincubated $90 \mathrm{~min}$ with $150 \mathrm{nM}$ myriocin and subsequently co-incubated with

$1350 \mu \mathrm{M}$ celecoxib/5 $\mu \mathrm{M}$ sphingosine $\left(\mathrm{C}_{17}\right) / 150 \quad \mathrm{nM}$ myriocin or with DMSO/5 $\mu \mathrm{M}$

14 sphingosine $\left(\mathrm{C}_{17}\right) / 150 \mathrm{nM}$ myriocin (control) for $2 \mathrm{~h}$. The amounts of ceramide $\left(\mathrm{C}_{17}\right)$ were

15 determined by LC-MS/MS. For analysis the area under the peak of the analyte was related to the

16 area under the peak of the internal standard. The relative increase of the specific ceramides was

17 calculated using the ratio analyte to internal standard of DMSO-treated cells as 100\% value. The

18 ceramide ratios were normalized to the number of treated cells. Data are mean \pm s. e. m. of one of

19 three comparable independent experiments each achieved in duplicate. $* * *(\mathrm{p}<0.001)$ indicate

20 significant difference between celecoxib treated and control cells.

23 Fig. 6. A) $\mathrm{C}_{16: 0}$-Cer level in HCT-116 cells after treatment with celecoxib and inhibitors of the de 24 novo synthesis or salvage pathway. HCT-116 cells were preincubated (90 min) with $70 \mu \mathrm{M}$ FB1, 
$1150 \mathrm{nM}$ myriocin or DMSO and subsequently treated with DMSO (control), $50 \mu \mathrm{M}$ celecoxib, 70

$2 \mu \mathrm{M}$ FB1, $50 \mu \mathrm{M}$ celecoxib/70 $\mu \mathrm{M}$ FB1, $150 \mathrm{nM}$ myriocin, $150 \mathrm{nM}$ myriocin/50 $\mu \mathrm{M}$ celecoxib

3 for $6 \mathrm{~h} . \mathrm{B} / \mathrm{C})$ The sphingosine $(\mathrm{B})$ and $\mathrm{C}_{16: 0}$-Cer (C) level in HCT-116 cells after treatment with

4 celecoxib and desipramine. HCT-116 cells were preincubated (90 min) with $20 \mu \mathrm{M}$ desipramine

5 or DMSO and subsequently treated with DMSO (control), $50 \mu \mathrm{M}$ celecoxib, $20 \mu \mathrm{M}$ desipramine

6 and $50 \mu \mathrm{M}$ celecoxib/20 $\mu \mathrm{M}$ desipramine for $6 \mathrm{~h}$. The $\mathrm{C}_{16: 0}$-Cer and sphingosine levels

7 determined with LC-MS/MS were normalized to the number of treated cells. Data are mean $\pm \mathrm{s}$.

8 e. $\mathrm{m}$. of two independent experiments each achieved in duplicate. A significant increase of $\mathrm{C}_{16: 0^{-}}$

9 Cer and sphingosine as indicated are marked with an asterisk $(* \mathrm{p}<0.05, * * * \mathrm{p}<0.001)$.

10 Abbreviations: Cel, celecoxib; FB1, fumonisin B1; Myr, myriocin, Desip, desipramine.

13 Fig. 7. Effects of orally administered celecoxib on the $\mathrm{C}_{16: 0}-\mathrm{Cer}(\mathrm{A}), \mathrm{C}_{24: 1}$-Cer (B) and $\mathrm{C}_{24: 0^{-}}-\mathrm{Cer}$ 14 (C) ceramide level in mouse tissue. Approximately $1 \times 10^{7}$ HCT-116 tumor cells were injected 15 subcutaneously into the left and right dorsal flank of nude mice. Mice received either vehicle or $1610 \mathrm{mg} / \mathrm{kg}$ celecoxib daily. Treatment started 4 days post implantation. After three weeks the mice 17 were sacrificed, the tissues (brain, heart, lung, liver, stomach (stom.), kidney, small intestine (s. 18 int.), large intestine (1. int.), testis, tumor) were extracted, washed with $0.9 \%$ saline and the 19 amount of ceramides were determined using LC-MS/MS. A significant increase of ceramide 20 amount in celecoxib-treated mice versus untreated control mice is indicated with an asterisk (*p $21<0.05, * * * \mathrm{p}<0.001)$. 
1 Fig. 8. Effect of CerS6 silencing on celecoxib-induced cell toxicity. HCT-116 cells were

2 pretreated with $62.5 \mathrm{nMol}$ CerS6 siRNA or with $62.5 \mathrm{nMol}$ scrambled siRNA (control) for $41 \mathrm{~h}$

3 and subsequently treated either with $50 \mu \mathrm{M}$ celecoxib or with DMSO for $20 \mathrm{~h}$. Cell viability was

4 determined using the WST-1 proliferation assay. Data are mean \pm s. e. $\mathrm{m}$. of one of three

5 comparable independent experiments each achieved in duplicate. * $(\mathrm{p}<0.01)$ indicate significant

6 difference between scrambled siRNA and CerS6 siRNA treated cells. 
Figure 1

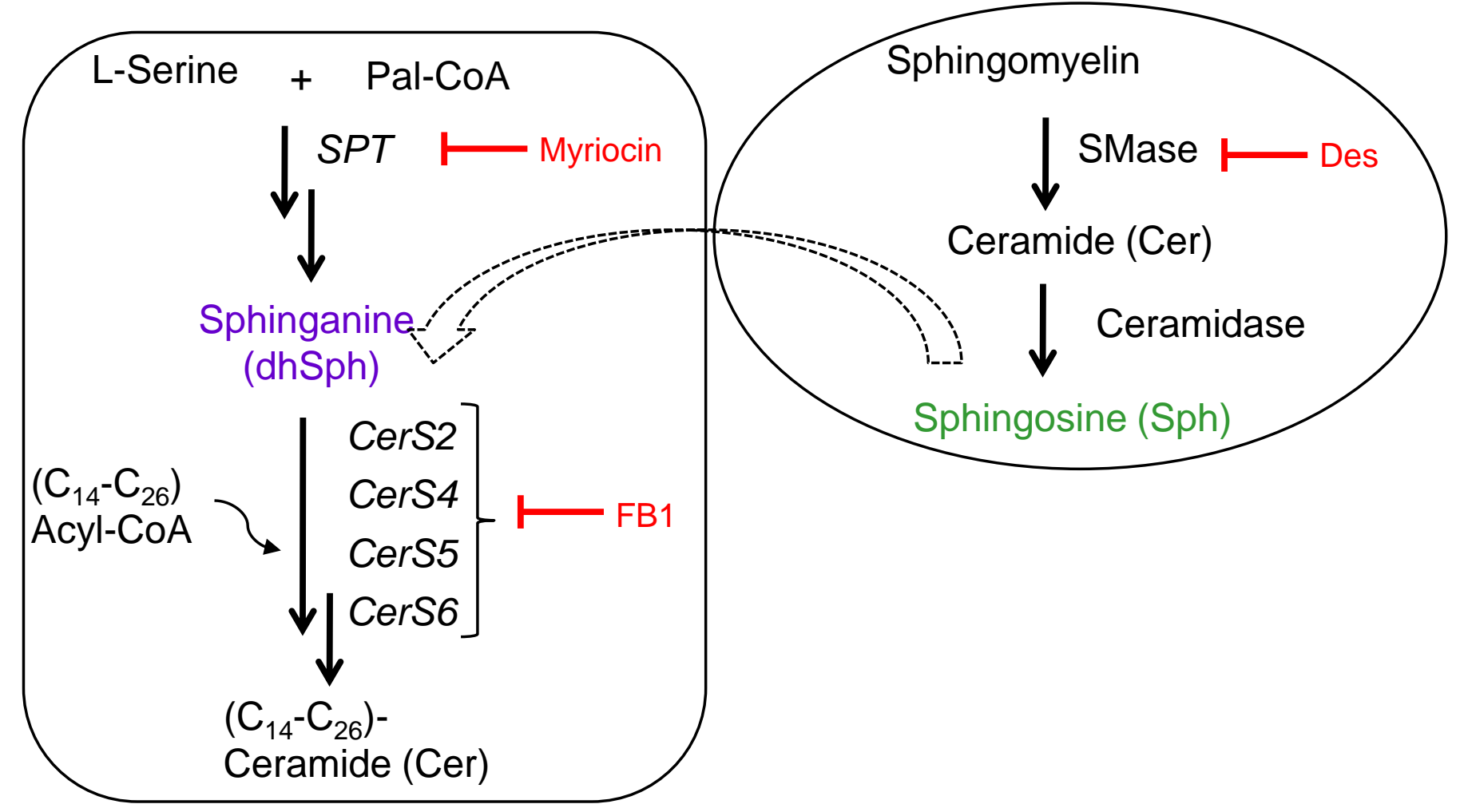

de novo Pathway

Salvage Pathway

B)

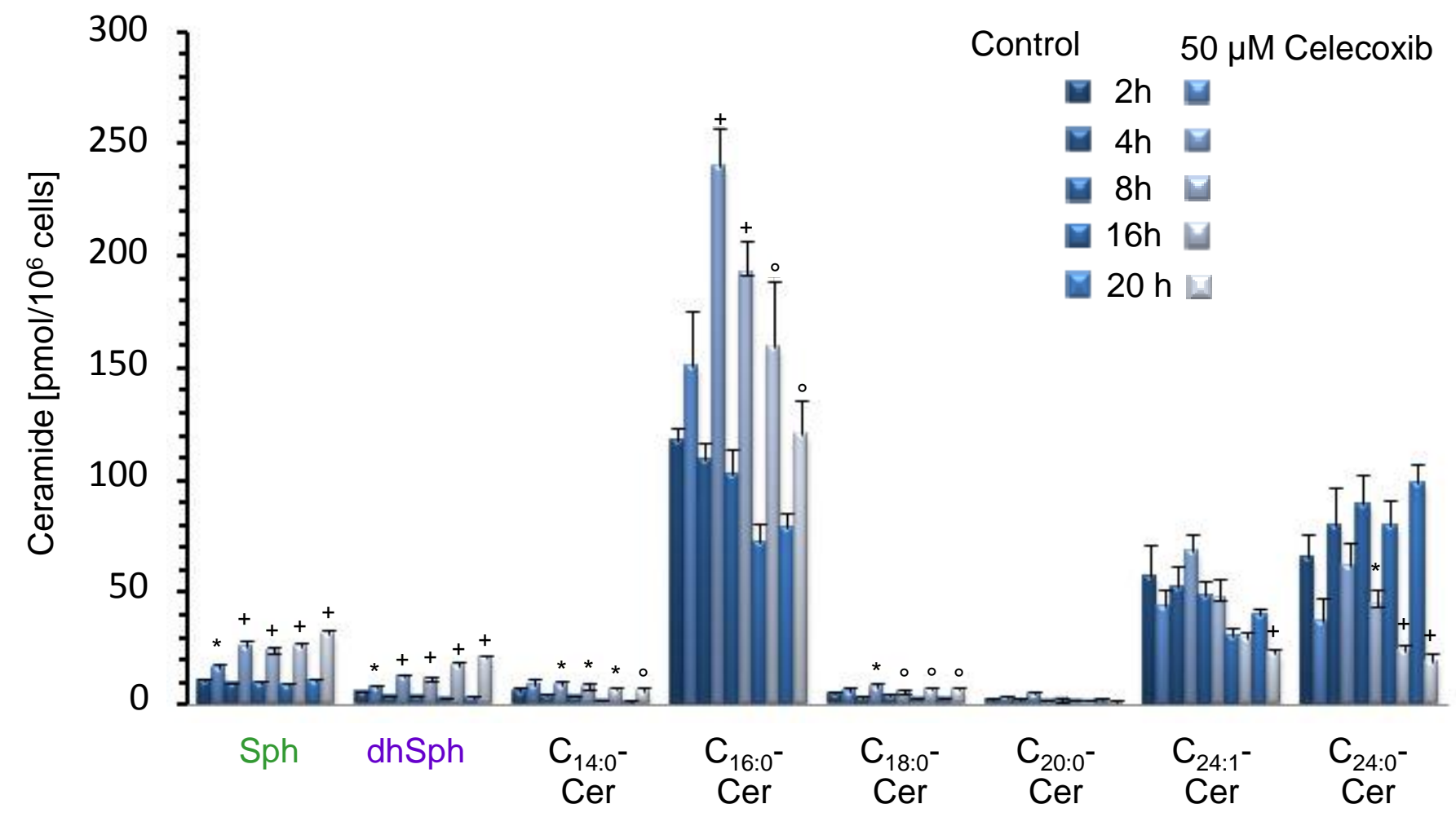


Figure 2

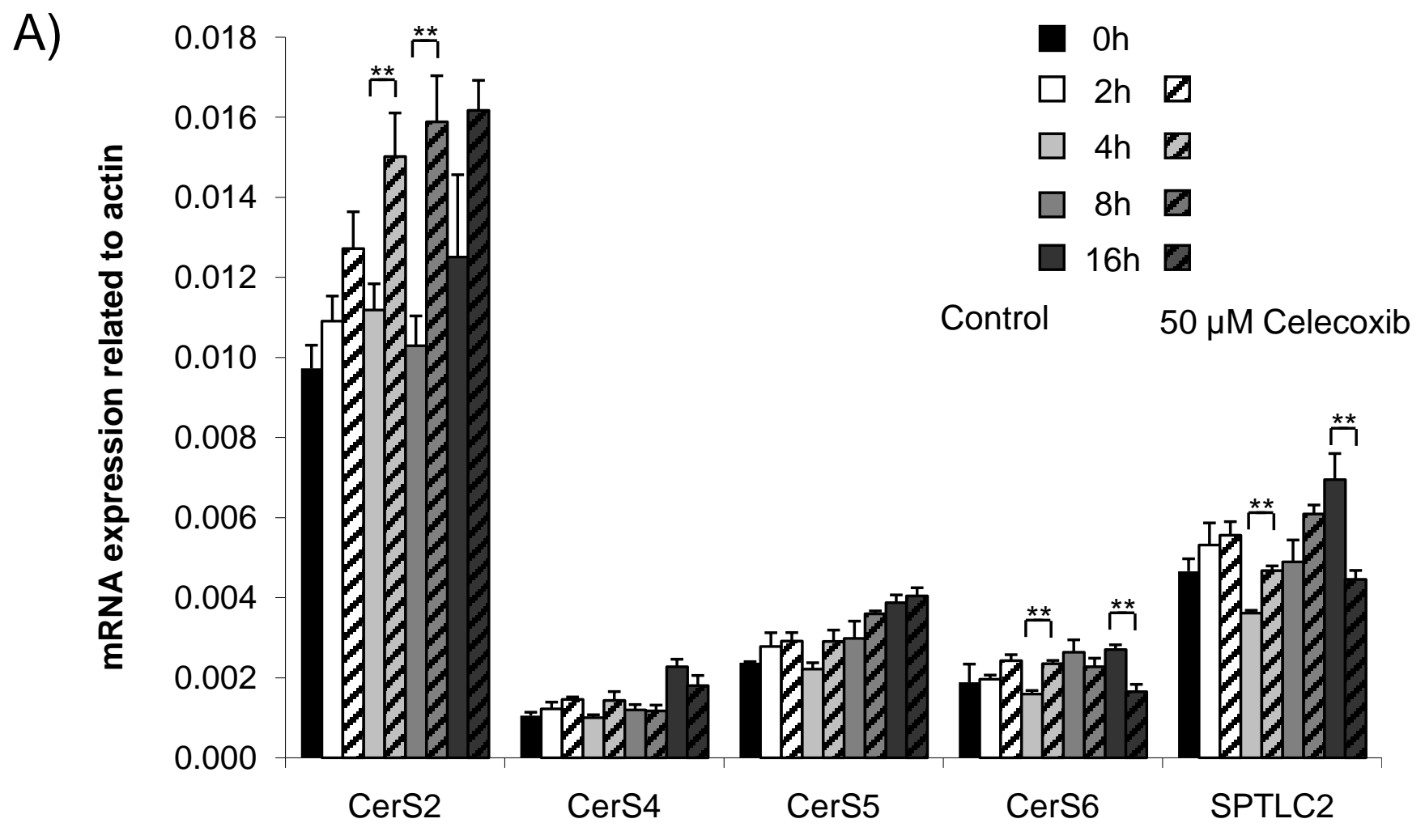

B)
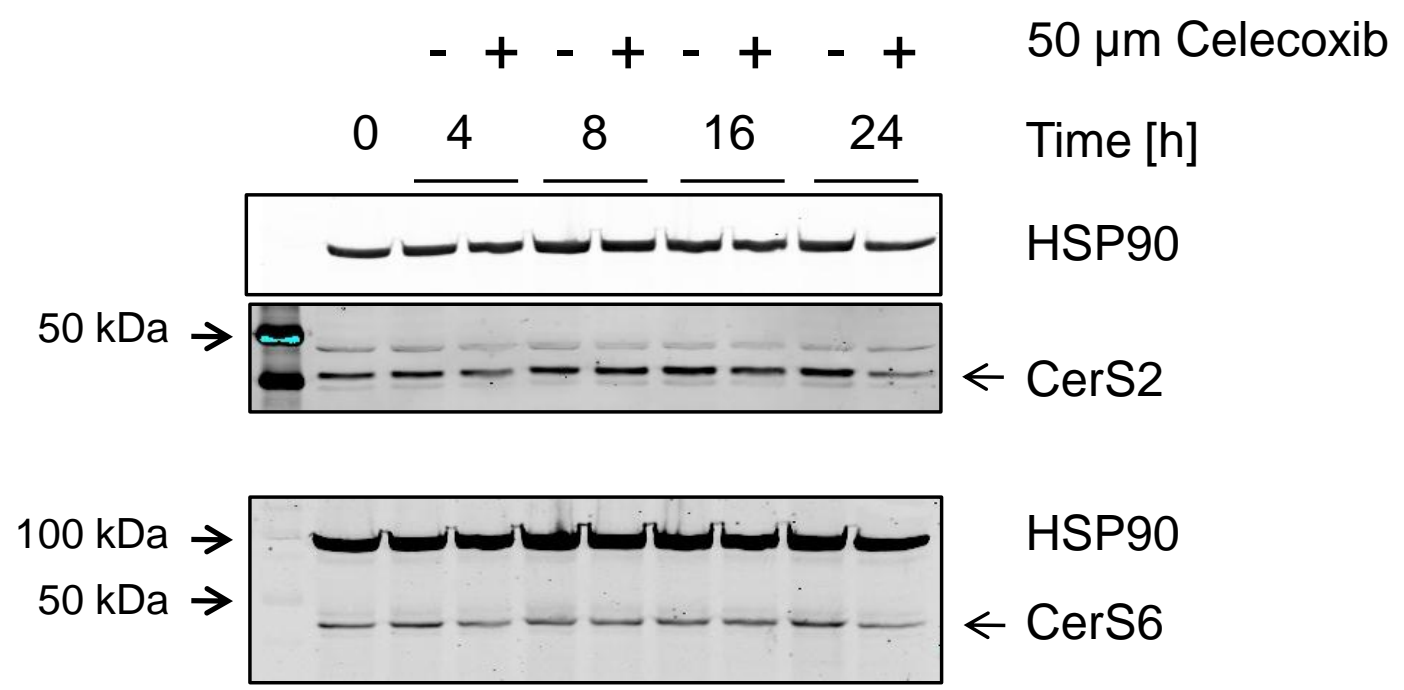
A)

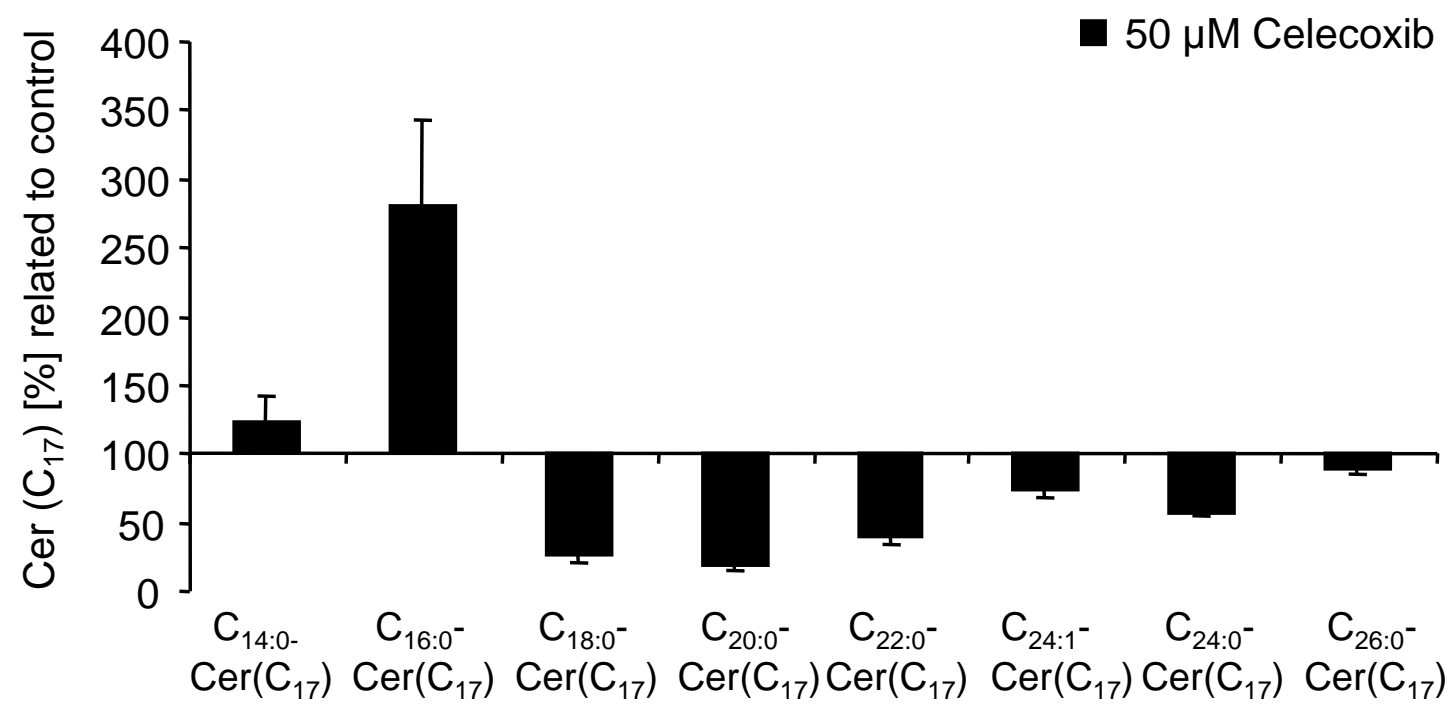

B)

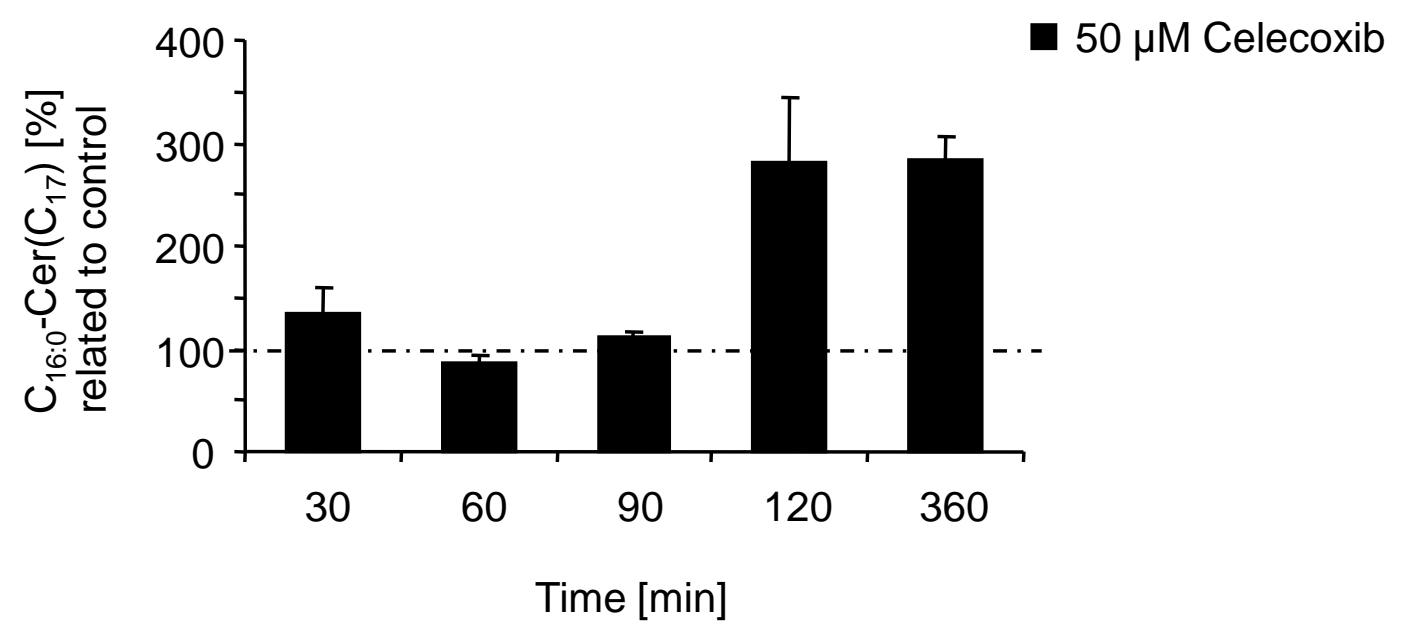


Figure 4

$\square$ Control

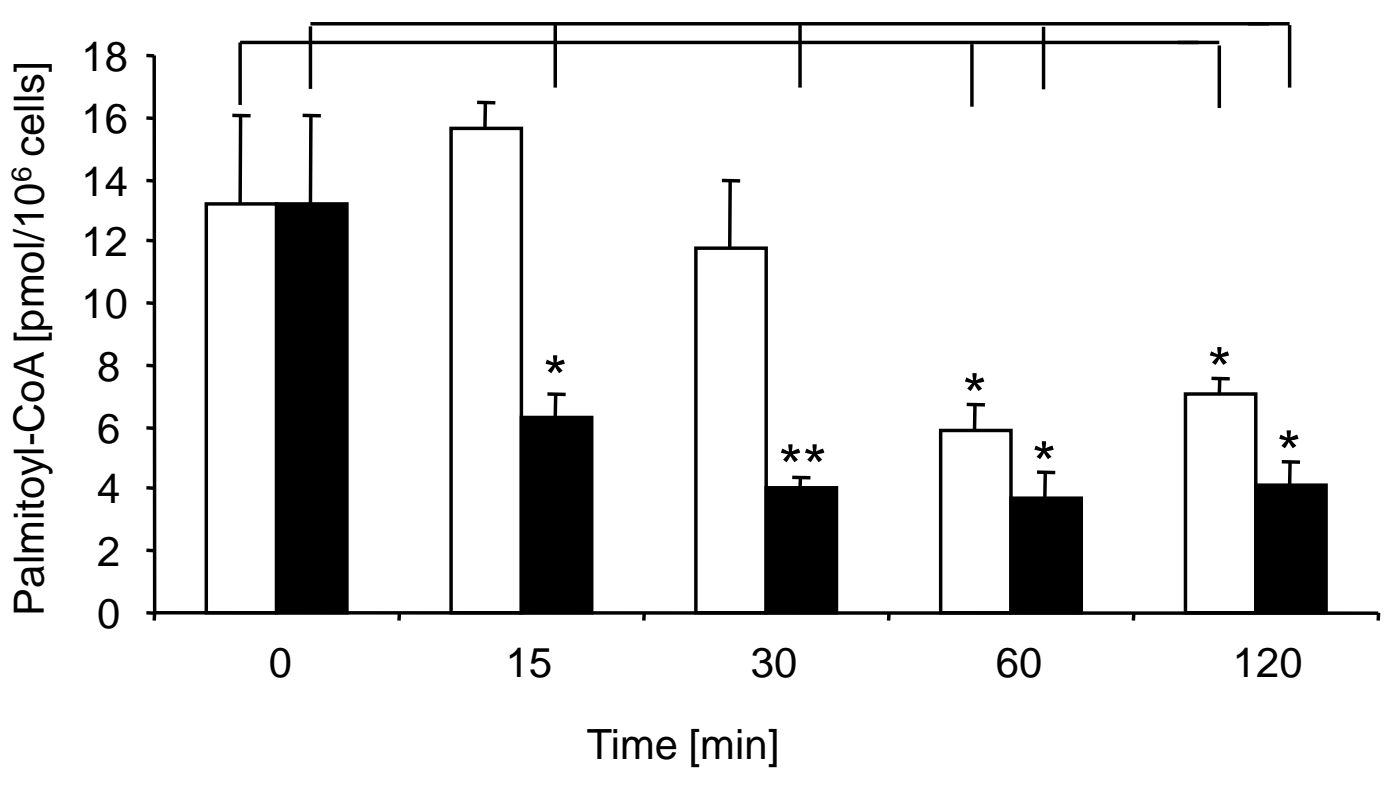

Figure 4

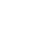
A)
- $50 \mu \mathrm{M}$ Celecoxib

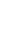

政



A) $\frac{\bar{d}}{\frac{\mathbb{T}}{\Phi}} \quad 1.6 \quad$ mRNA levels in siRNA treated HCT-116 cells

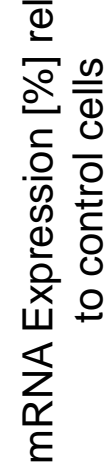
1.4
1.2
1.0
0.8
0.6
0.4
0.2
0.0

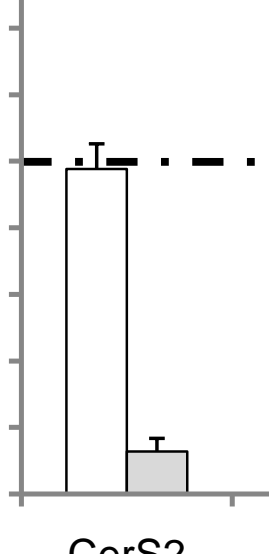
Cers2
CerS4
CerS5
CerS6
Actin

B) $\left.\quad \begin{array}{r}180 \\ \bar{D}\end{array}\right] \quad$ Ceramide levels in siRNA treated HCT-116 cells

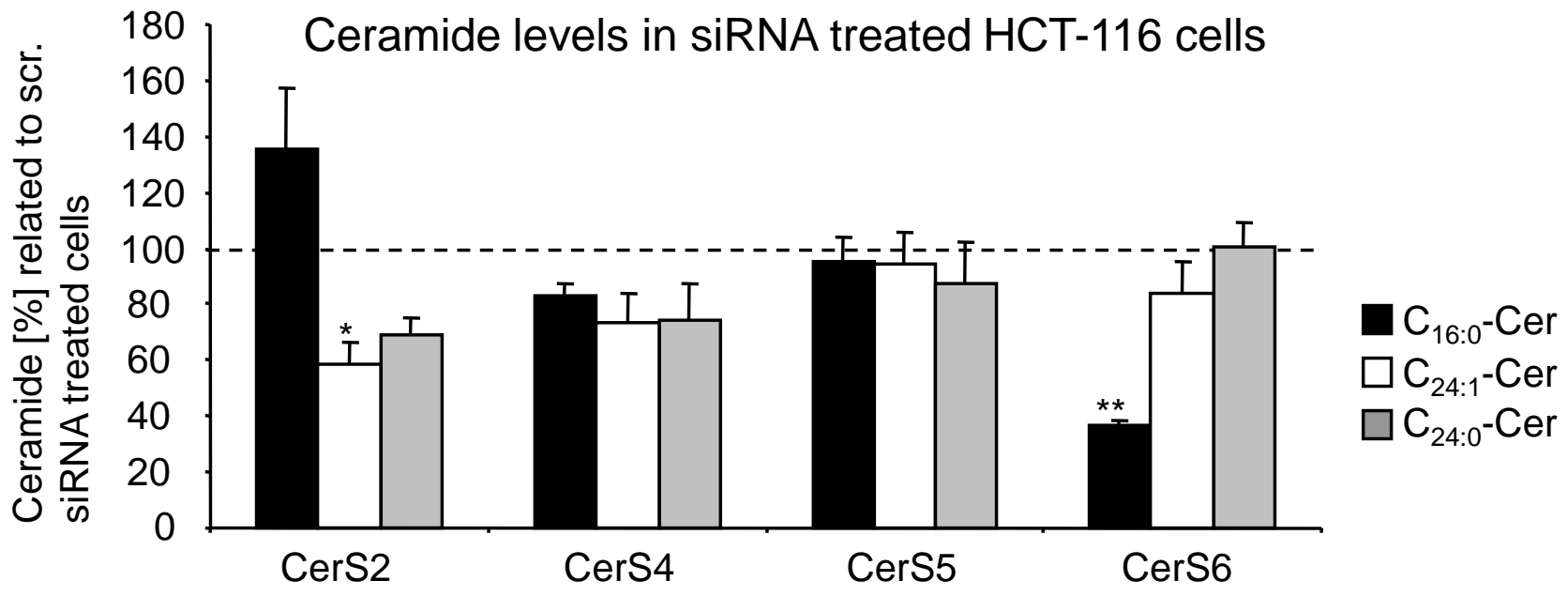

Activity assay in siRNA treated HCT-116 cells

C)

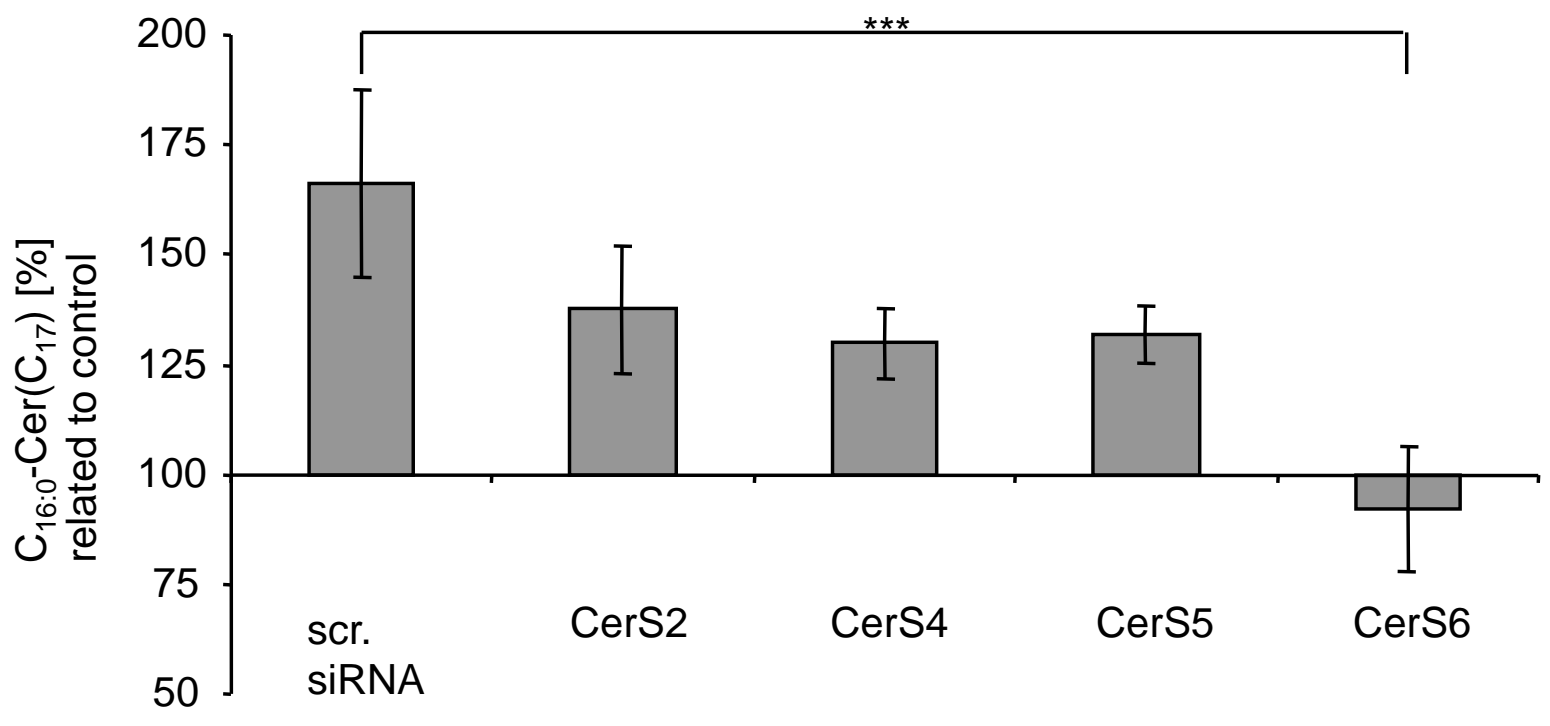


A)

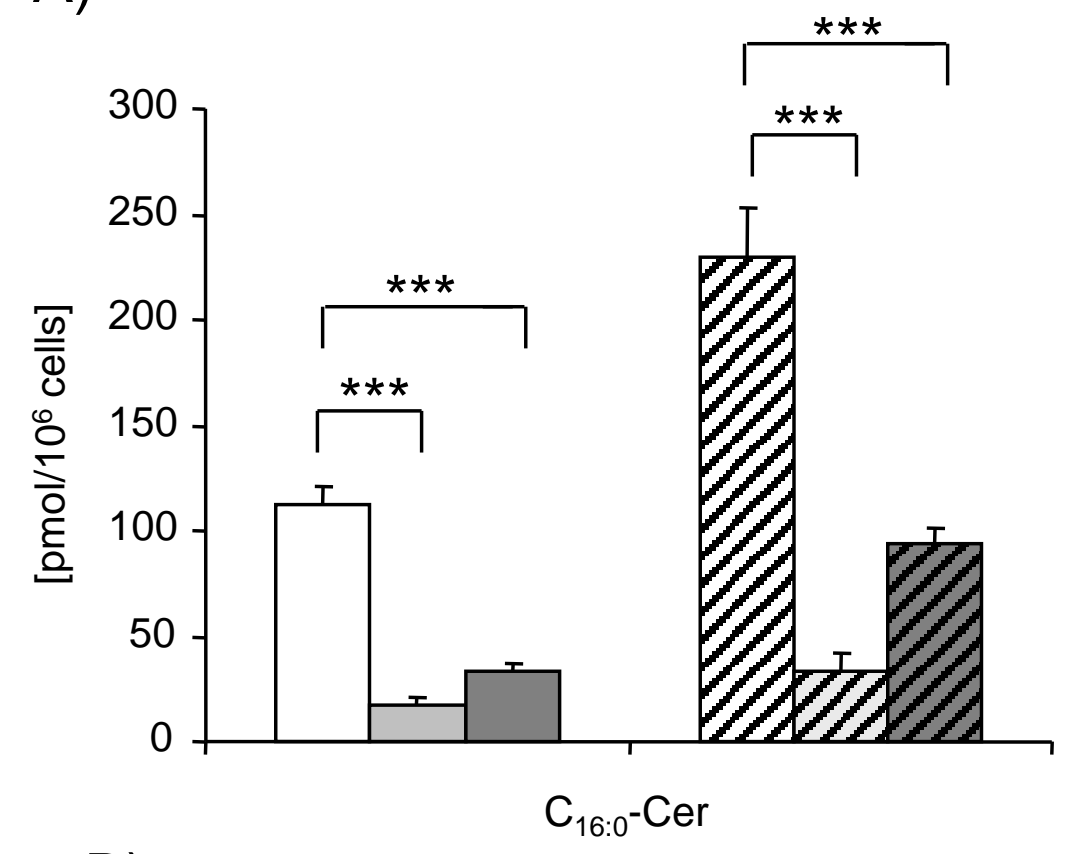

B)

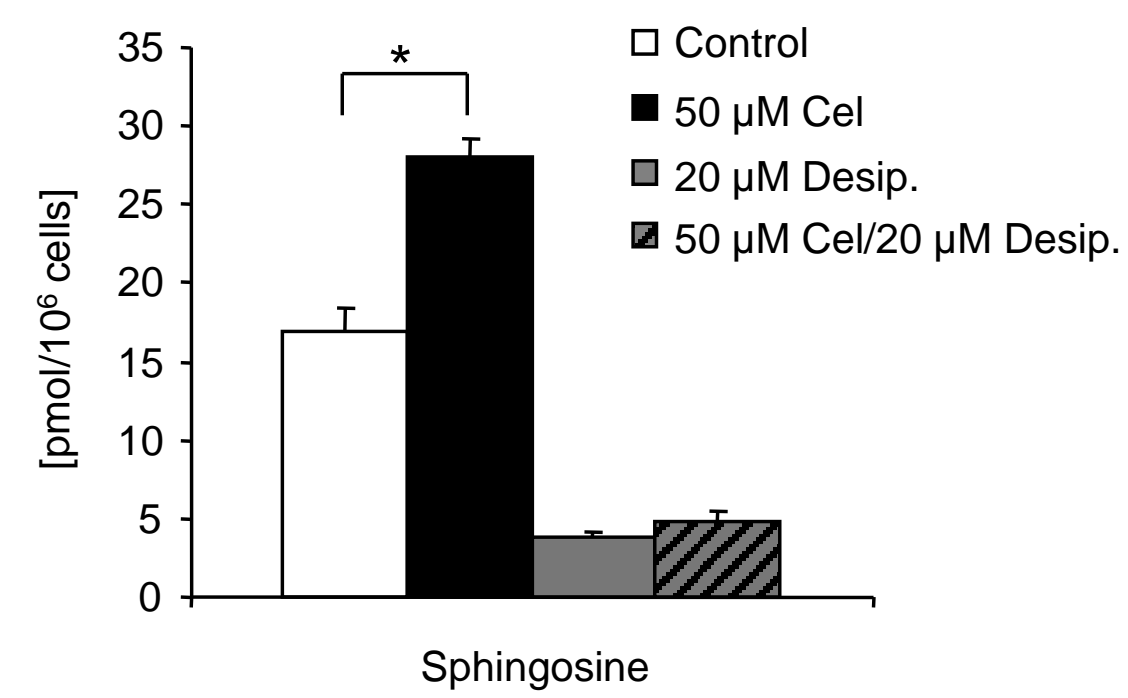

Figure 6

\author{
$\square$ Control \\ $\square 70 \mu \mathrm{M}$ FB1 \\ $\square 150 \mathrm{nM}$ Myr \\ $\square 50 \mu \mathrm{M}$ Cel \\ $\square 50 \mu \mathrm{M}$ Cel/70 $\mu \mathrm{M}$ FB1 \\ \ $50 \mu \mathrm{M} \mathrm{Cel} / 150 \mathrm{nM}$ Myr
}

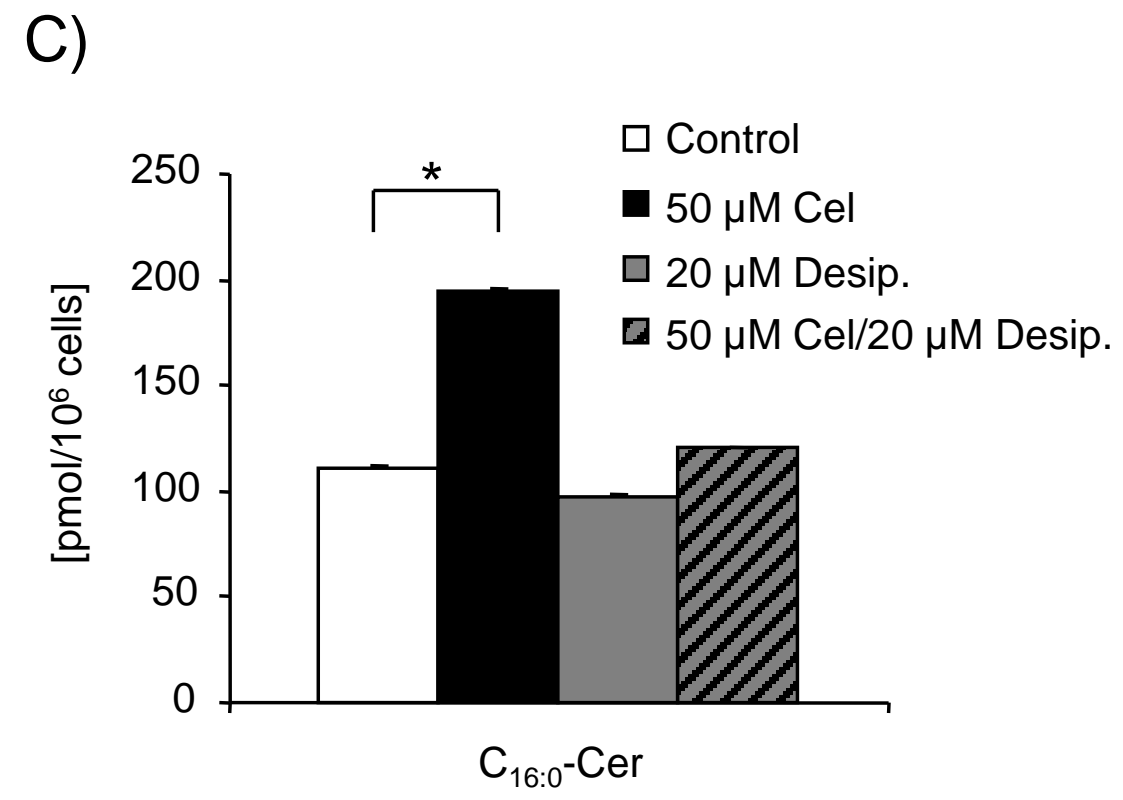


A)

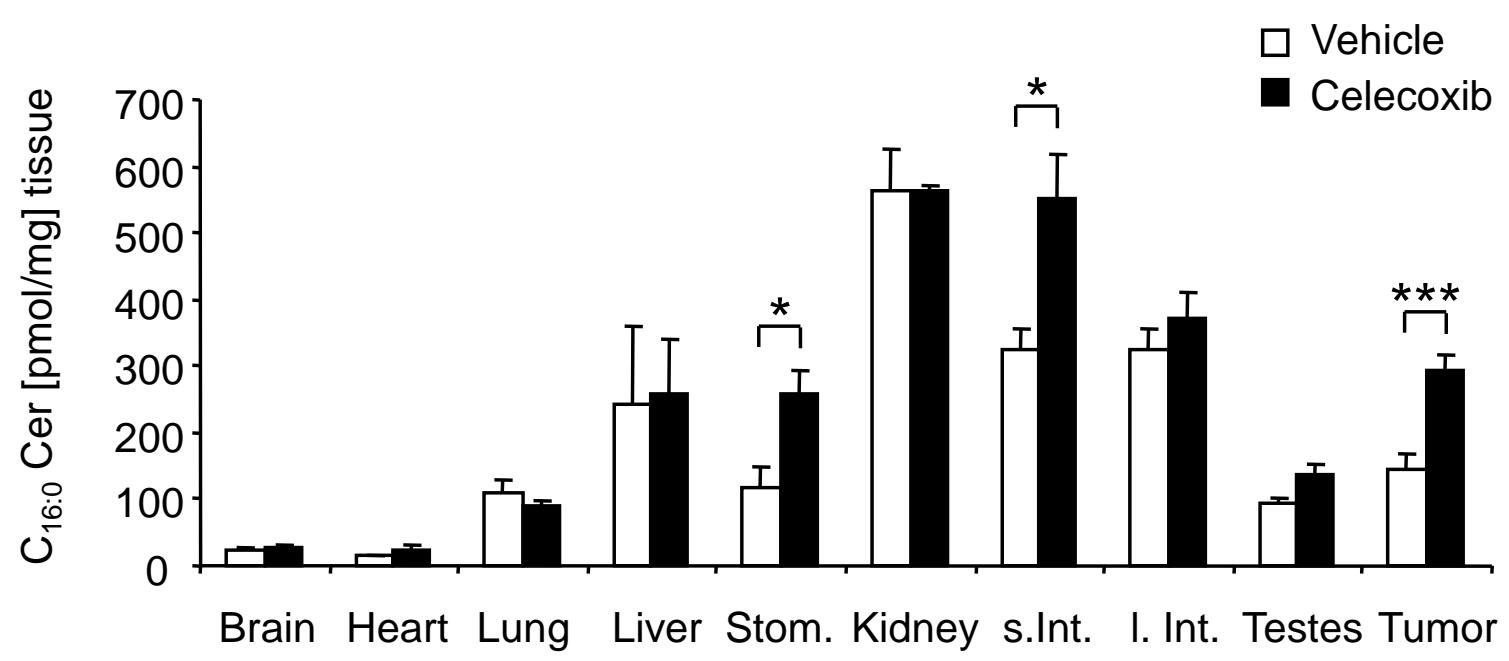

B)

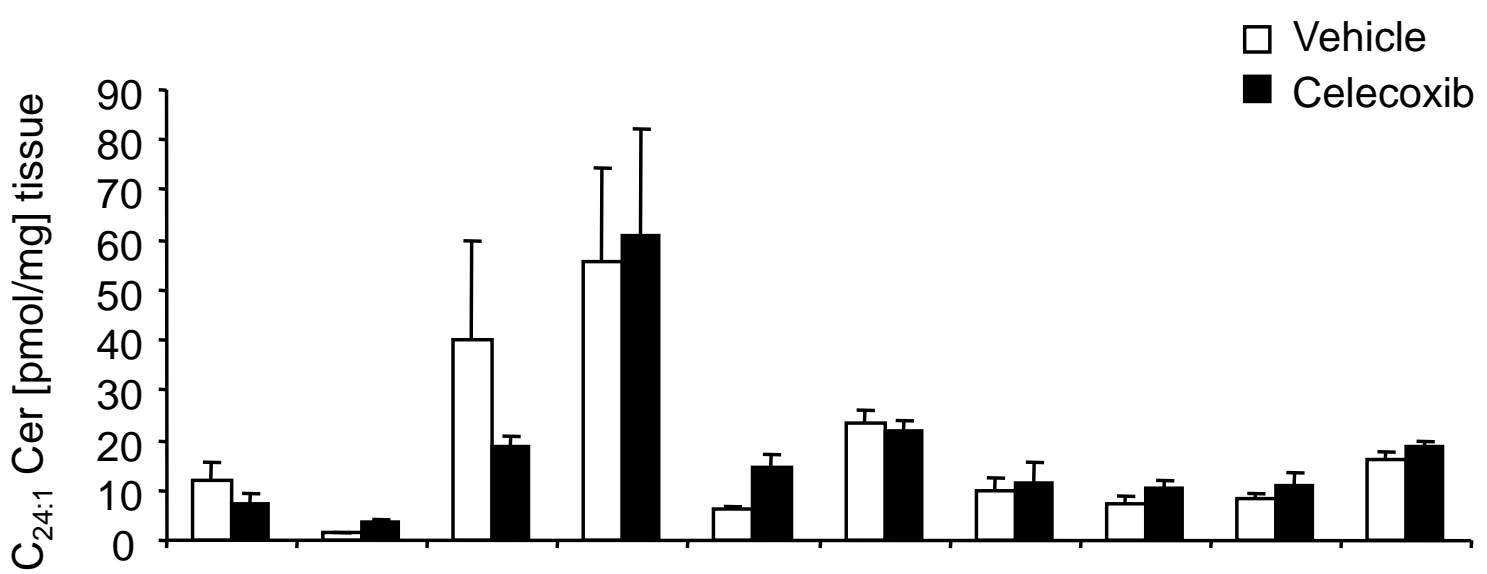

Brain Heart Lung Liver Stom. Kidney s. Int. I. Int. Testes Tumor

C)

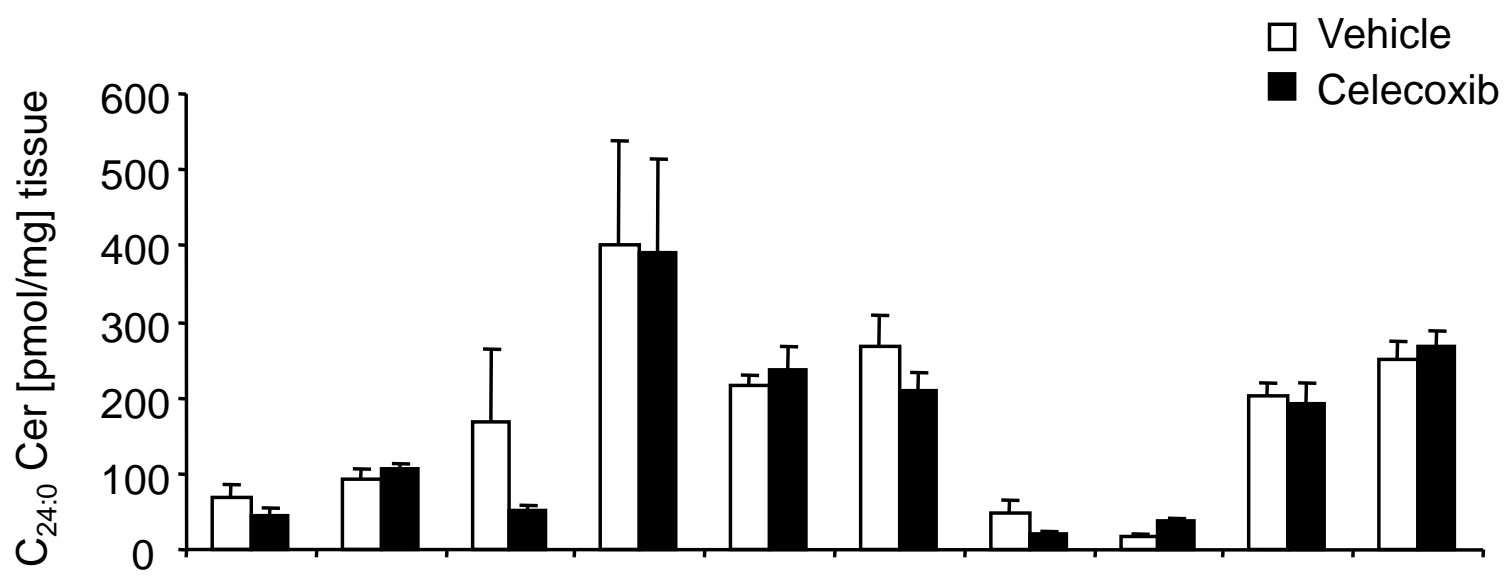

Brain Heart Lung Liver Stom. Kidney s. Int. I. Int. Testes Tumor 


\section{Figure 8}

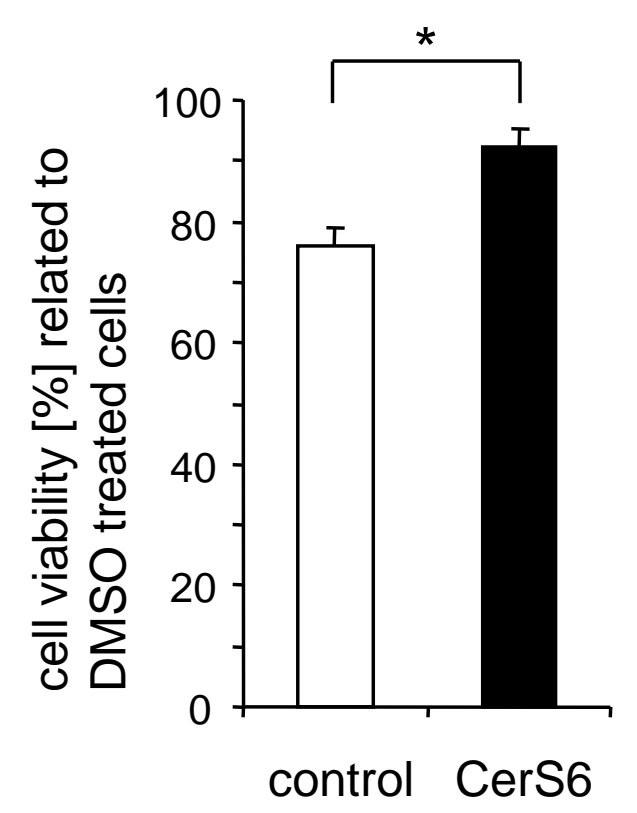




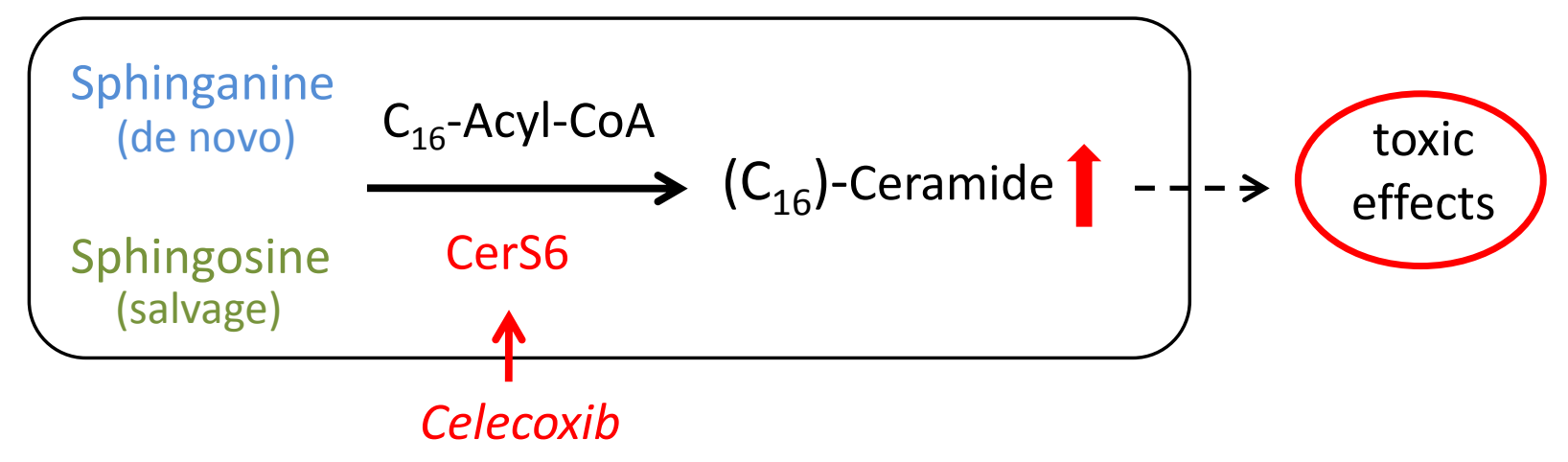

Treatment of cancer cells with celecoxib led to a significant increase of $\mathrm{C}_{16: 0}$-Cer via the specific activation of ceramide synthase 6 (CerS6). The increase in $C_{16: 0}$-Cer contributes in part to the proapoptotic effect of celecoxib. 
Figure for reviewer II

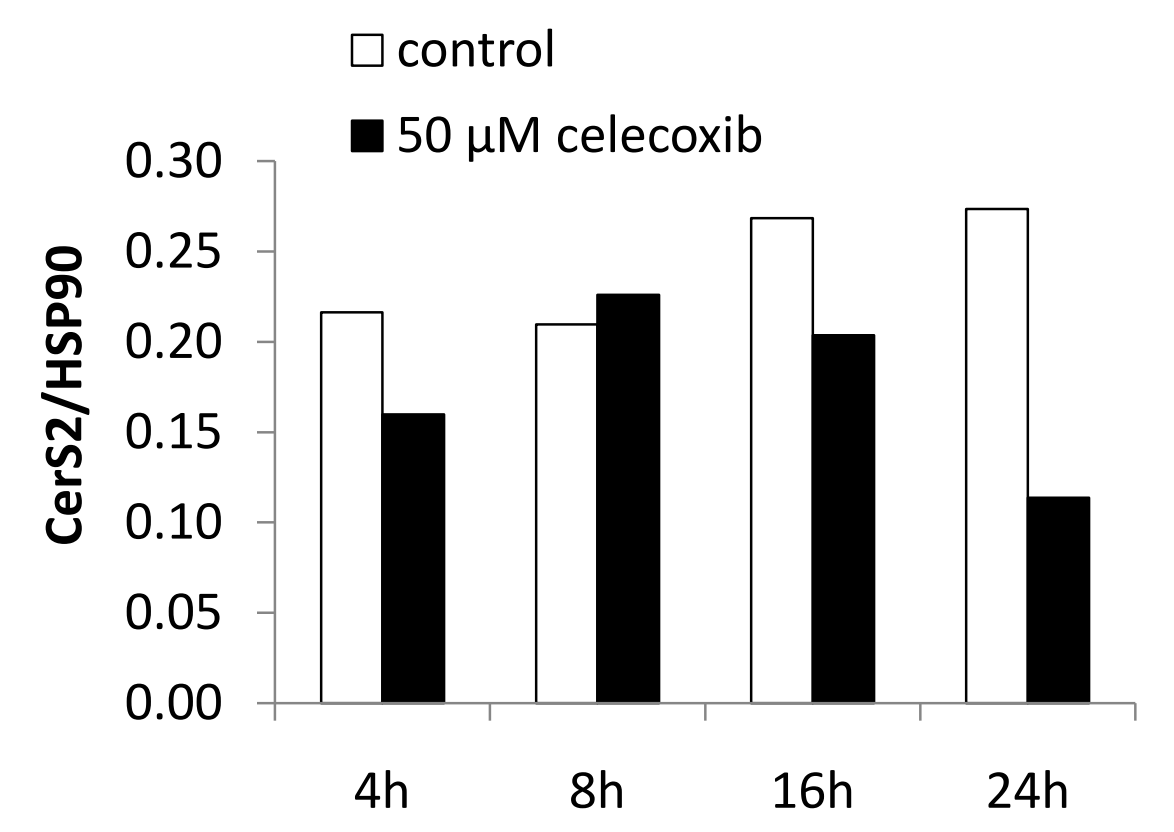

Figure: Densitometric analyses of western blot of CerS2 (Figure 2A) 